\title{
Review of studies on hydrological modelling in Malaysia
}

\author{
J. H. Abdulkareem ${ }^{1,2} \cdot$ B. Pradhan ${ }^{3} \cdot$ W. N. A. Sulaiman ${ }^{1} \cdot$ N. R. Jamil ${ }^{1}$ \\ Received: 30 June 2018 / Accepted: 28 August 2018 / Published online: 12 September 2018 \\ (c) Springer Nature Switzerland AG 2018
}

\begin{abstract}
Hydrological models are vital component and essential tools for water resources and environmental planning and management. In recent times, several studies have been conducted with a view of examining the compatibility of model results with streamflow measurements. Some modelers are of the view that even the use of complex modeling techniques does not give better assessment due to soil heterogeneity and climatic changes that plays vital roles in the behavior of streamflow. In Malaysia, several public domain hydrologic models that range from physically-based models, empirical models and conceptual models are in use. These include hydrologic modeling system (HEC-HMS), soil water assessment tool (SWAT), MIKE-SHE, artificial neural network (ANN). In view of this, a study was conducted to evaluate the hydrological models used in Malaysia, determine the coverage of the hydrological models in major river basins and to identify the methodologies used (specifically model performance and evaluation). The results of the review showed that $65 \%$ of the studies conducted used physical-based models, $37 \%$ used empirical models while $6 \%$ used conceptual models. Of the $65 \%$ of physical-based modelling studies, 60\% utilized HEC-HMS an open source models, 20\% used SWAT (public domain model), $9 \%$ used MIKE-SHE, MIKE 11 and MIKE 22, Infoworks RS occupied 7\% while TREX and IFAS occupy 2\% each. Thus, indicating preference for open access models in Malaysia. In the case of empirical models, $46 \%$ from the total of empirical researches in Malaysia used ANN, 13\% used Logistic Regression (LR), while Fuzzy logic, Unit Hydrograph, Auto-regressive integrated moving average (ARIMA) model and support vector machine (SVM) contributed $8 \%$ each. Whereas the remaining proportion is occupied by Numerical weather prediction (NWP), land surface model (LSM), frequency ratio (FR), decision tree (DT) and weight of evidence (WoE). Majority of the hydrological modelling studies utilized one or more statistical measure of evaluating hydrological model performance $\left(R, R^{2}\right.$, NSE, RMSE, MAE, etc.) except in some few cases where no specific method was stated. Of the 70 papers reviewed in this study, 16 did not specify the type of model evaluation criteria they used in evaluating their studies, 17 utilized only one method while 37 used two or more methods. NSE with $27 \%$ was found to be the most widely used method of evaluating model performance; $R$ and RMSE came second with a percentage use $24 \%$ each. $R^{2}(20 \%)$ was recorded as the third most widely used model evaluation criteria in Malaysia, MAE came fourth with $16 \%$ while PBIAS is the least with $11 \%$.The findings of this work will serve as a guide to modelers in identifying the type of hydrological model they need to apply to a particular catchment for a particular problem. It will equally help water resources managers and policy makers in providing them with executive summary of hydrological studies and where more input is needed to achieve sustainable development.
\end{abstract}

Keywords Hydrologic models $\cdot$ Review $\cdot$ Malaysia $\cdot$ GIS $\cdot$ HEC-HMS $\cdot$ SWAT

\footnotetext{
J. H. Abdulkareem

jhabdulkareem@abu.edu.ng

$\triangle$ B. Pradhan

biswajeet24@gmail.com; Biswajeet.Pradhan@uts.edu.au

1 Department of Environmental Science, Faculty of Environmental Studies, Universiti Putra Malaysia (UPM), 43400 Serdang, Selangor, Malaysia
}

2 Department of Soil Science, Institute for Agricultural Research/Faculty of Agriculture, Ahmadu Bello University, P.M.B, 1044 Zaria, Nigeria

3 The Centre for Advanced Modelling and Geospatial Information Systems (CAMGIS), Faculty of Engineering and Information Technology, University of Technology Sydney, Sydney, NSW 2007, Australia 


\section{Introduction}

According to Penman (1961), hydrology is the science that deals with the aftermath of activities that follows a rainfall event. In another related definition by Ray (1975), hydrology is a branch of science that deals with global water resources occurrence, distribution and circulation as well as their physical and chemical characteristics and how they react to the environment (their relationship with biotic organisms included). Hydrology is concerned with the interconnection of water resources with the environment as they appear in each segment of the hydrologic cycle. (Devi et al. 2015). Hydrology encompasses all phases of earth's water which makes it essential to human lives as well as the environment (Chow et al. 1988).

There are several practical uses directly associated with the science of hydrology e.g. flood disaster management, planning for water supply, design and operation of hydraulic structures, pollution abatement, wastewater, irrigation, erosion and sediment control among others (McCuen 1998; Shaw et al. 2010; Khalid et al. 2016). In general, hydrology gives guidance for planning, management and control of water resources by applying engineering and geography principles that are fundamental for its study. Land use/land cover (LULC) changes due to urbanization, deforestation, industrialization, irrigation and other forms of changes have now been added to the hydrologic systems (Abdulkareem et al. 2017, 2018a). Others such as climate change and soil heterogeneity that are reported to have a direct effect on streamflow across the globe are also considered (Devi et al. 2015). As a result of these, different hydrologic models were developed to assess the effect of LULC change, soil characteristics and climate change on watersheds.

A model can be regarded as a simple illustration of real world system (Devi et al. 2015). Models are generally used for forecasting the performance and interpretation of different hydrological processes. They comprise of several parameters that describe their features. Although hydrological models are developed to examine the relationship between water, LULC, soil and climate change, rainfall and drainage area are the two most important hydrological model parameters to always consider.. This along with other watershed characteristics such as topography, geology and ground water aquifer are also given adequate consideration during model development (Alam et al. 2011; Devi et al. 2015; Khalid et al. 2016). As a result, several models were developed for simulating the hydrological behavior of a watershed for both surface and ground water modeling. Such models are categorized as either deterministic or stochastic, empirical, conceptual or physically based (Refsgaard 1996; Khalid et al. 2016).
The use of computer models in simulating catchment hydrological processes for runoff estimation has been inexistence for over five decades (Boughton 2006). Recently it has been the most widely used technique for water resources management and hydrological design work, with a variety of models available for use. Hydrological models are developed in such a way that, when inputted with good quality data they give good simulation results and the reverse is the case, as no model will give good simulation from faulty data. In a nutshell, hydrological model results depend on the quality of input data, rather than the model (Boughton 2006). They are vital component and essential tools for water resources and environmental management (Devi et al. 2015). They can be used to examine the quantity and quality of streamflow, groundwater development and protection, reservoir system operations, surface water and groundwater conjunctive use management, water use, groundwater development and protection, water distribution systems, as well as other water resources management strategies (Wurbs 1998; Singh and Woolhiser 2002). Although hydrological modelling of floods and droughts are significant for planning and management, this area is faced with scarcity of major input parameters, which limits its application to rainfall-runoff models. For instance, rainfall measurements are only carried out on selected areas, streamflow measurement is done at few locations (Bárdossy 2006).

Ever since when hydrologic models were discovered, real life experiments (manual way of mapping and updating LULC changes) are considered expensive and time consuming. As such, hydrologic models have been used as computational laboratories for testing the hypothesis of hydrological behavior of watersheds. Hydrological models are normally used for estimating basin's hydrological response to rainfall. The choice of a model depends on the watershed and the objective of the hydrological prediction in the watershed (Halwatura and Najim 2013). Hydrological models make available a simplified representation of an actual watershed system to obtain a better understanding of hydrological processes in the study area.

Currently there exist very few reviews with respect to hydrological studies in Malaysia. For instance, the review conducted by Khalid et al. (2016) focused only on physically based models (precisely SWAT model). In their findings, they reported that the model has been applied in both longterm and short-term simulation purposes and on different watersheds. Abdullah (2013) carried out a review on hydrological modelling in Malaysia but gave emphasis to 1D, 1D-2D, 2D, and 3D models. Another attempt by Jajarmizadeh et al. (2012), focus only on reviewing theoretical considerations and type of models in hydrology without much emphasis on the Malaysian perspective. Based on the recent challenges regarding climate change, LULC changes such as rapid urbanization, deforestation for logging and agricultural 
activities, the hydrological system of many watersheds in the country were transformed or being transformed. As such, several studies regarding the hydrological behavior concerning to climate change and LULC changes are being carried out. Therefore, there is need for a wider review that will cover the whole country, to have a clear view of the status of hydrological studies conducted in Malaysia. Such review will be useful to water resource managers, decision makers and land use planners for future planning and development especially in effective prediction of streamflow changes. In view of this, this review on hydrological studies in Malaysia attempts to evaluate the hydrological models used in Malaysia, determine the coverage of hydrological models in major river basins and to identify the methodologies used (specifically model performance and evaluation).

\section{General and hydrological description of the study area}

Malaysia is one of the southeast Asian countries located on latitude $2^{\circ} 30^{\prime} \mathrm{N}$ and longitude $112^{\circ} 30^{\prime} \mathrm{E}$. It has an estimated population of about 30.33 million (UNPF 2015) covering an area of $329,750 \mathrm{~km}^{2}$. It is divided into West and East Malaysia by South China Sea. West Malaysia (peninsular Malaysia) with 11 states shares a maritime border with Thailand from the north, Singapore and Indonesia from the south and southwest respectively. East Malaysia (Malaysian Borneo) has 2 states viz; Sabah and Sarawak shares a maritime border with Indonesia to the south and Philippines to the north. The country is characterized with a tropical climate receiving an average annual rainfall of over $2800 \mathrm{~mm}$. Average temperature ranges between 21 and $30{ }^{\circ} \mathrm{C}$ while humidity range from 80 to 90\% (Manaf et al. 2009; Kura et al. 2015).

Peninsular Malaysia is classified into different hydrological regions for water resources assessment. Geological characteristics and climatic factors that are important in water flow were considered in this classification. Lithology or rock porosity is the major geological feature selected while for the climatic factors, annual rainfall and annual evapotranspiration were merged together to formulate a climatic parameter used for delineation. From the lithological point of view, five lithological groups were identified from hydrogeological map of Malaysia (Chong and Tan 1986; Omang and Tahir 1994; Heng 2004) as shown in Fig. 1. Hydrological boundaries in Malaysia were demarcated by the boundaries of these lithological groups. Hydrological sub-boundaries were drawn from conditional surface water resources map of Peninsular Malaysia (DID 1974). Figure 2 shows the map of Malaysia indicating major catchments and sub-catchments. Average annual surface water yield $(W)$ with regards to potential runoff isolines is presented by this map. Isolines are obtained as the difference between annual average rainfall $(P)$ and average annual potential evapotranspiratation

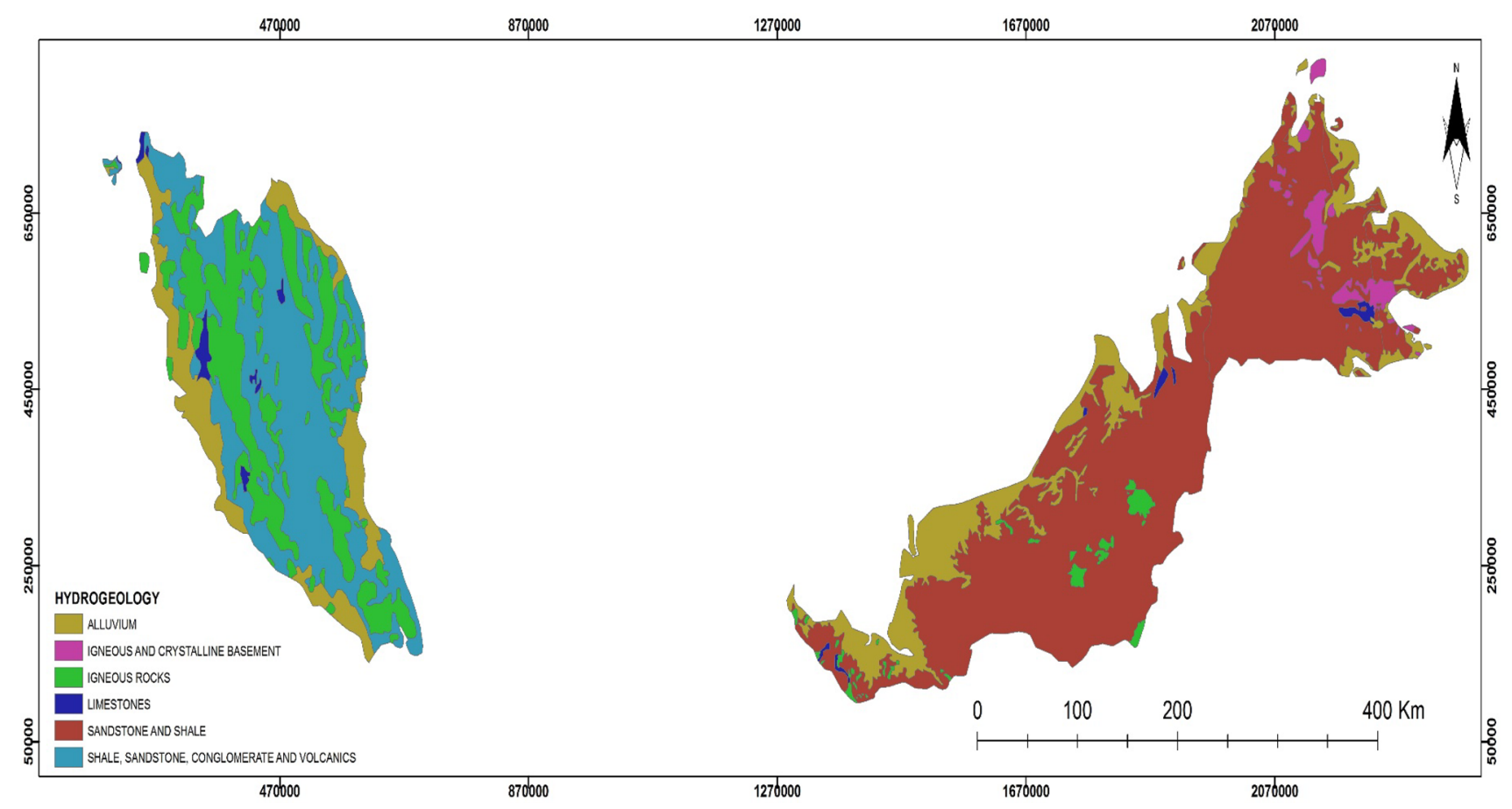

Fig. 1 Simplified hydrogeological map of Malaysia (left: Peninsular Malaysia, right: Malaysian Borneo; Sabah and Sarawak). Modified from (Chong and Tan 1986; Omang and Tahir 1994; Heng 2004) 


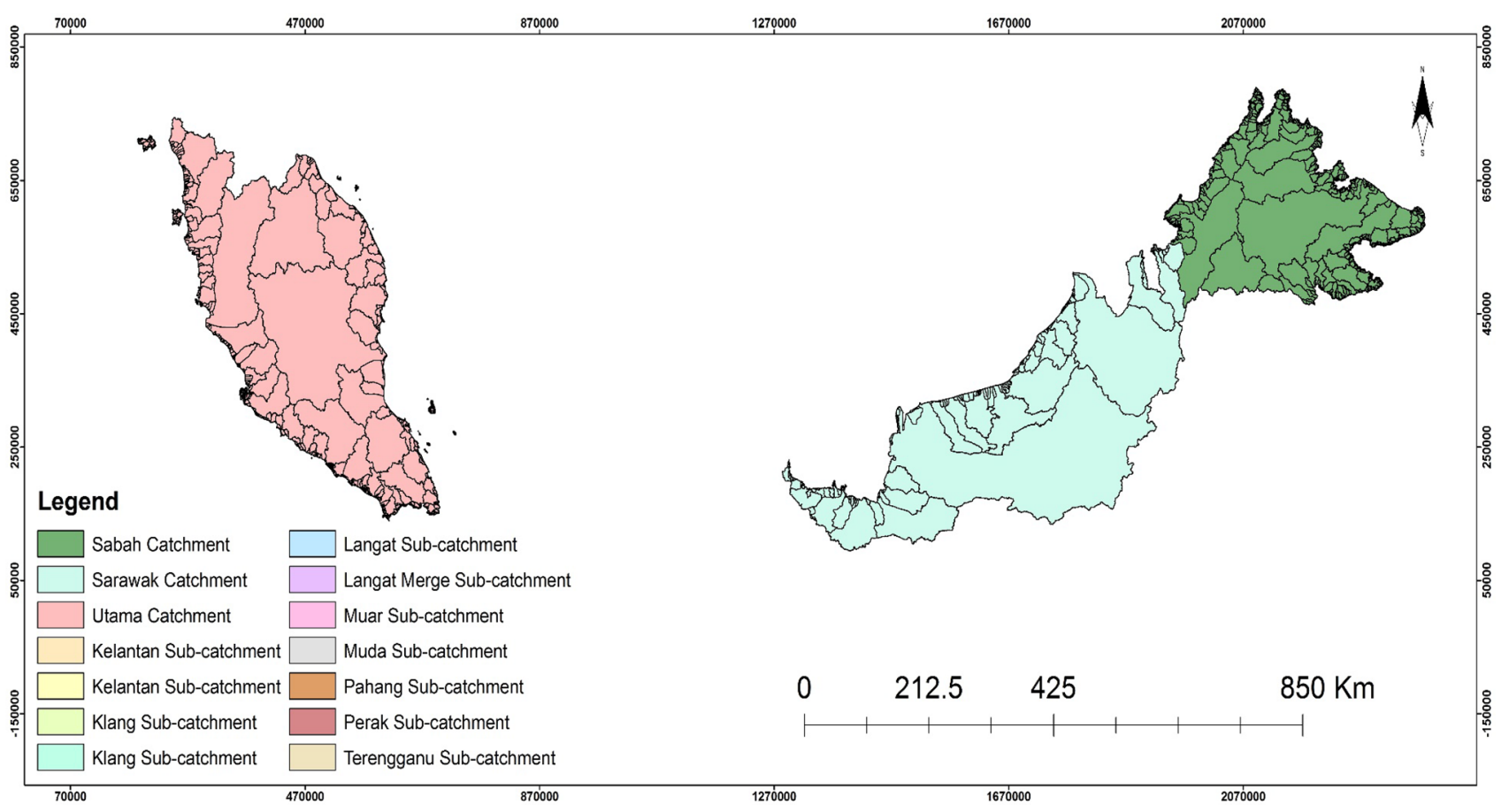

Fig. 2 Map of Malaysia showing major Catchments and Sub-catchments

(PE) as illustrated in the water balance equation $W=P-\mathrm{PE}$. Potential runoff isolines $(P-\mathrm{PE})$ are further categorized into broad groups whose boundaries were used as sub-boundaries. When lithological parameter $(L)$ was combined with $P-$ PE parameter $(W)$, a numerical classification system with five lithological groups $\left(L_{1}-L_{5}\right)$ and four $P$-PE groups $\left(W_{1}-W_{4}\right)$ giving a possible combination of twenty classes. The Peninsular Malaysia was classified with the aid of this system into sixty-six hydrological classes expecting hydrological similarities. Several regions have the same quantitative classification with each other.

\section{Classification of hydrological models}

Several attempts have been made by scientists in the past to classify hydrological models (Fleming 1972; Woolhiser 1973; Singh 1995). Devi et al. (2015) reported that hydrological models can be classified based on model input parameters as well the degree to which physical techniques are applied. The classification used in this study adopted from Refsgaard (1996) as shown in Fig. 3 classified hydrological models into deterministic, stochastic and joint stochastic-deterministic. Deterministic models are further sub-divided into physically-based model, conceptual model and empirical model. This classification can be applied to watershed models as well as single component models like the groundwater models. It should however, be noted that this classification is sketchy and that

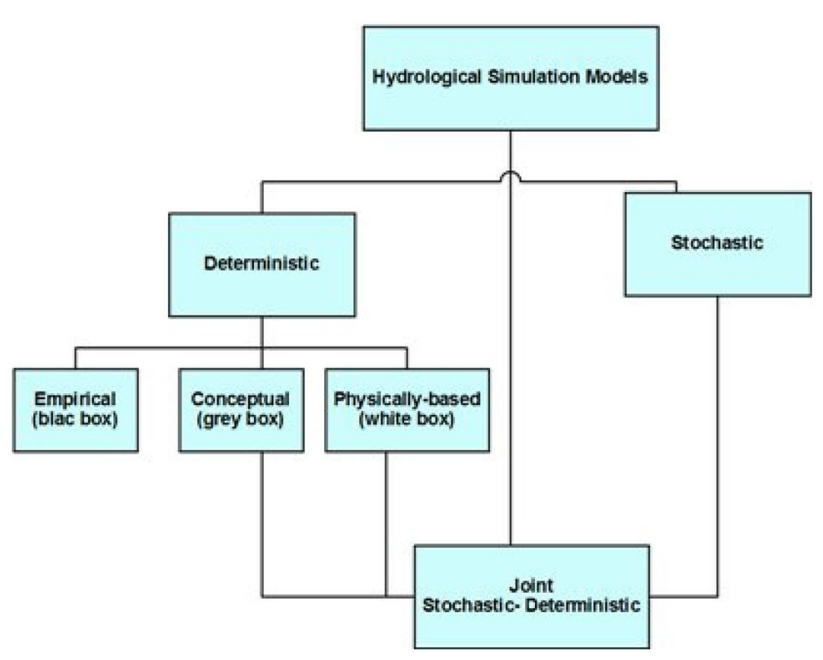

Fig. 3 Classification of hydrological models according to process description. (Modified from Refsgaard 1996)

fitting some model codes cannot be done exactly in the classes given by Refsgaard (1996). 


\section{Categories of hydrological modelling studies in Malaysia}

The sub-divisions of deterministic models were used in classifying hydrological modelling studies in Malaysia. From the results (Table 1) 65\% of the studies conducted used physically-based models, $37 \%$ used empirical models while $6 \%$ used conceptual models. Of the $65 \%$ of physically-based modelling studies, $60 \%$ utilized HEC-HMS an open access model, $20 \%$ used SWAT (public domain), $9 \%$ applieed MIKE-SHE, MIKE 11 and MIKE 22, Infoworks RS occupied 7\% while TREX and IFAS occupy $2 \%$ each. In the case of empirical models, $46 \%$ from the total of empirical researches in Malaysia used ANN, 13\% applied LR, while Fuzzy logic, UH, ARIMA and SVM contributed $8 \%$ each whereas the remaining proportion is occupied by NWP, LSM, FR, DT and WoE.

Selangor state recorded a total 21 hydrological studies from the review (Chang et al. 2017; Dlamini et al. 2017; Goh et al. 2016; Khalid et al. 2015). This could be attributed to numerous rivers in the state such as Sungai Kayu Aru River basin, Upper Bernam River basin, Klang, Langat River whose changing hydrological behaviors with response to LULC changes and climate change need to be regularly monitored. Johor and Kelantan were ranked second each with 17 hydrological researches in this review. This may be due to high incidence of flood disasters in Kelantan as reported by several authors (Tehrany et al. 2014; Kia et al. 2012; Pradhan and Youssef 2011). Sabah and Sarawak ranked third with 5 hydrological studies reviewed in this study. Pahang recorded 4 researches, Perak and Terengganu came fifth with 3 researches each. Two hydrological studies were recorded in Kedah (Table 1; Fig. 4).

\section{Deterministic models}

In deterministic models, a unit of input parameters will yield the same output. These models can be classified according to description of a watershed whether lumped or distributed. They can also be describe based on the hydrological processes in the catchment whether physically-based, empirical or conceptual. It should however, be noted that majority of physically-based models are also distributed and majority of conceptual models are lumped (Refsgaard 1996). The three main classes of deterministic models are illustrated in Fig. 3 and will be discussed below based on how they are being applied for hydrological modelling in Malaysia. Table 2 shows a summary of the general characteristics of deterministic models.

\section{Physically-based models}

Physically based-models are mathematical illustration of a real-life events. They are also referred to as mechanistic models and usually include the techniques of physical processes. These models require parameters that can be measured and are dependent upon both time and space. They have minimal hydrological and meteorological data requirement for calibration purpose but it involves the estimation several variables that represent the physical features of a catchment such as soil moisture content, initial water depth, topography, topology, etc. (Abbott et al. 1986a; Refsgaard 1996; Devi et al. 2015). Unlike conceptual models, physically-based models do not give attention to water movement in a watershed to occur between a few storage units. Rather hydrological processes involving water and energy movement are assessed from partial differential equations, e.g. Richards' equation for vadose zone flow, Boussinesq's equation for groundwater flow and Saint Venant equations for overland and channel routing. The outputs of physically-based models are more comprehensive and precise than that of other model classes. In addition, these models can generate more than half of information of a watershed that is being simulated. The principle of physically-based models can be applied for any hydrological problem and in cases where other hydrological models cannot be applied (Refsgaard 1996). Example of physically-based hydrological models commonly applied in Malaysia for hydrological are HEC-HMS (USACE-HEC 2000), SWAT (Arnold et al. 2005), MIKE SHE (Refsgaard and Storm 1995).

\section{HEC-HMS model}

The Hydrologic Engineering Center-Hydrologic Modeling System (HEC-HMS) a watershed-scale open access hydrologic model was developed by United States Army Corps of Engineers Hydrologic Engineering Center (HEC). HEC-HMS like many physically-based hydrologic models simulate most of the major hydrologic processes at a watershed scale. The model system comprises of losses, runoff transform, open-channel routing, analysis of meteorological data, rainfall-runoff simulation, and parameter estimation (USACE-HEC 2010). It uses distinct models to represent each component of the runoff process, as well as models that compute runoff volume, models of direct runoff, and models of baseflow. Every individual model run a combine basin model, meteorological model, and control specifications with run options to obtain results. The system of connectivity and physical data describing 


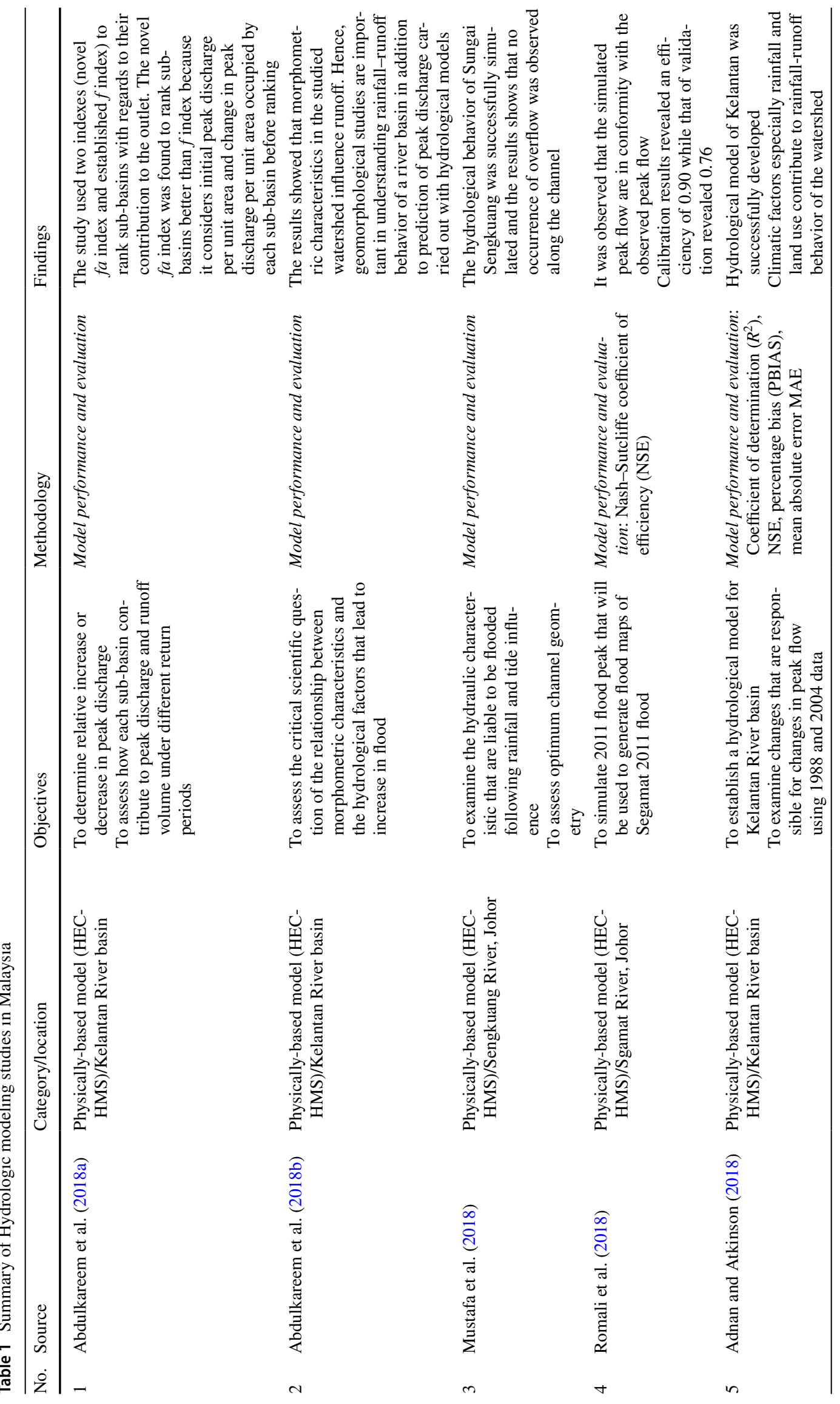




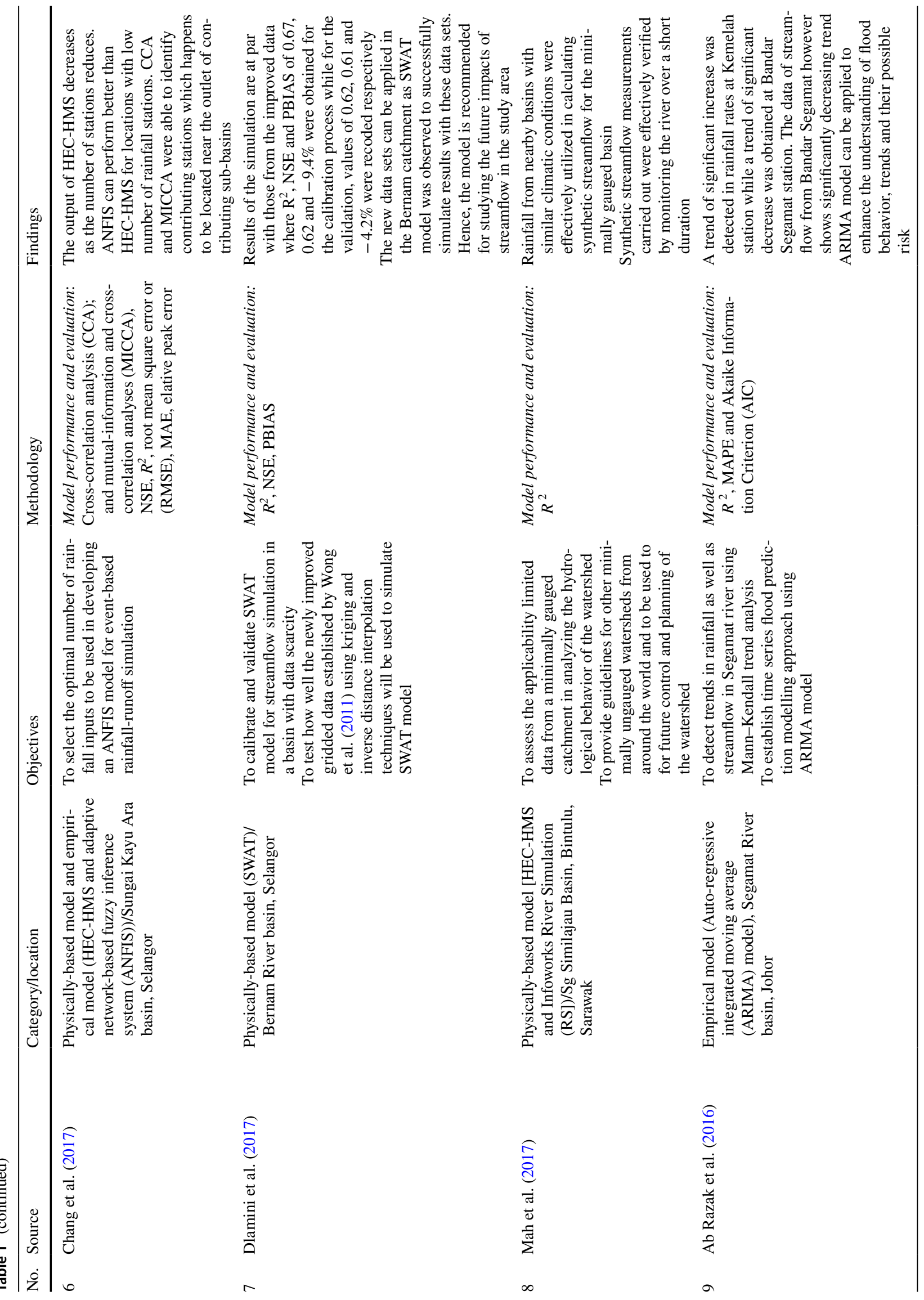




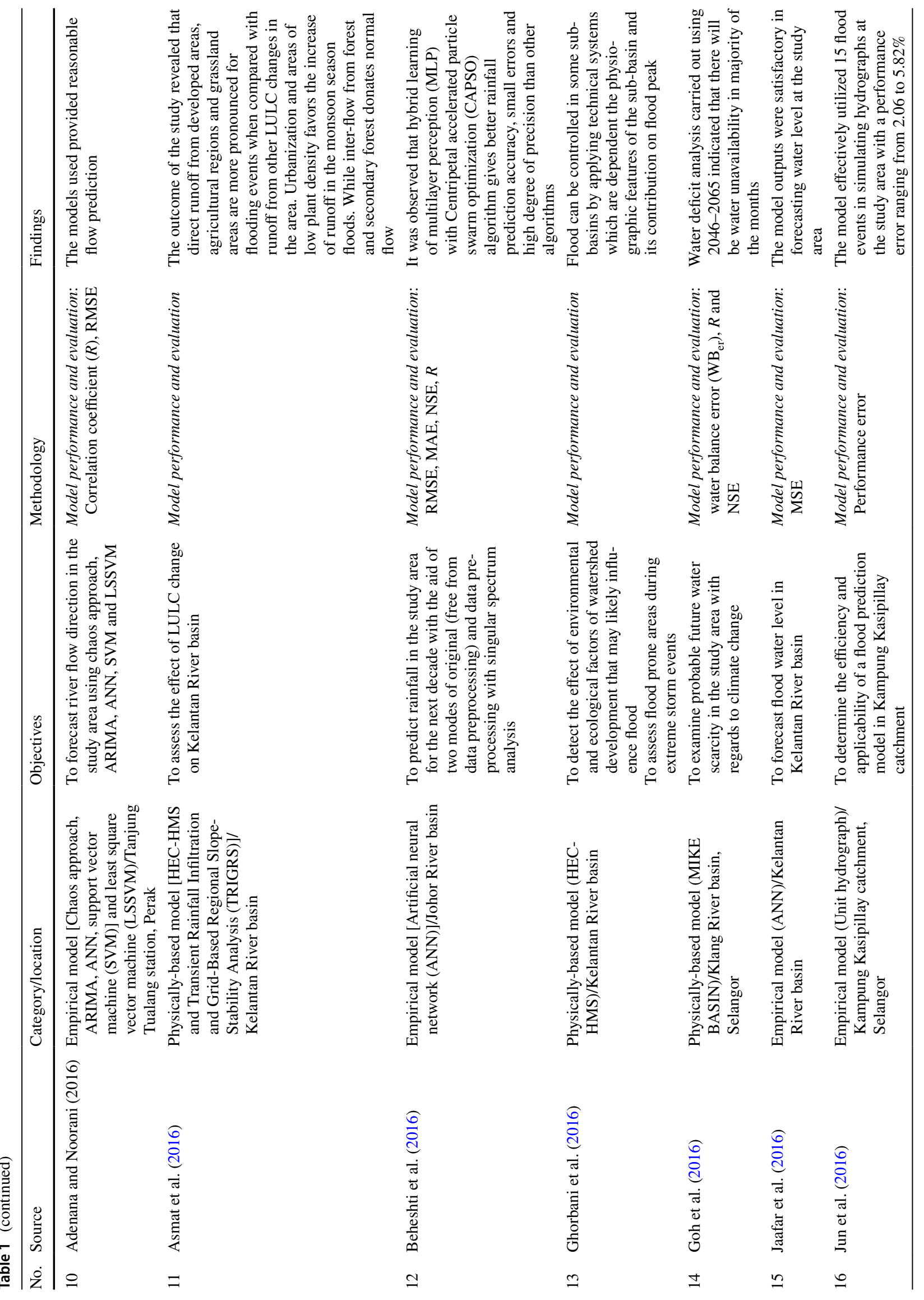




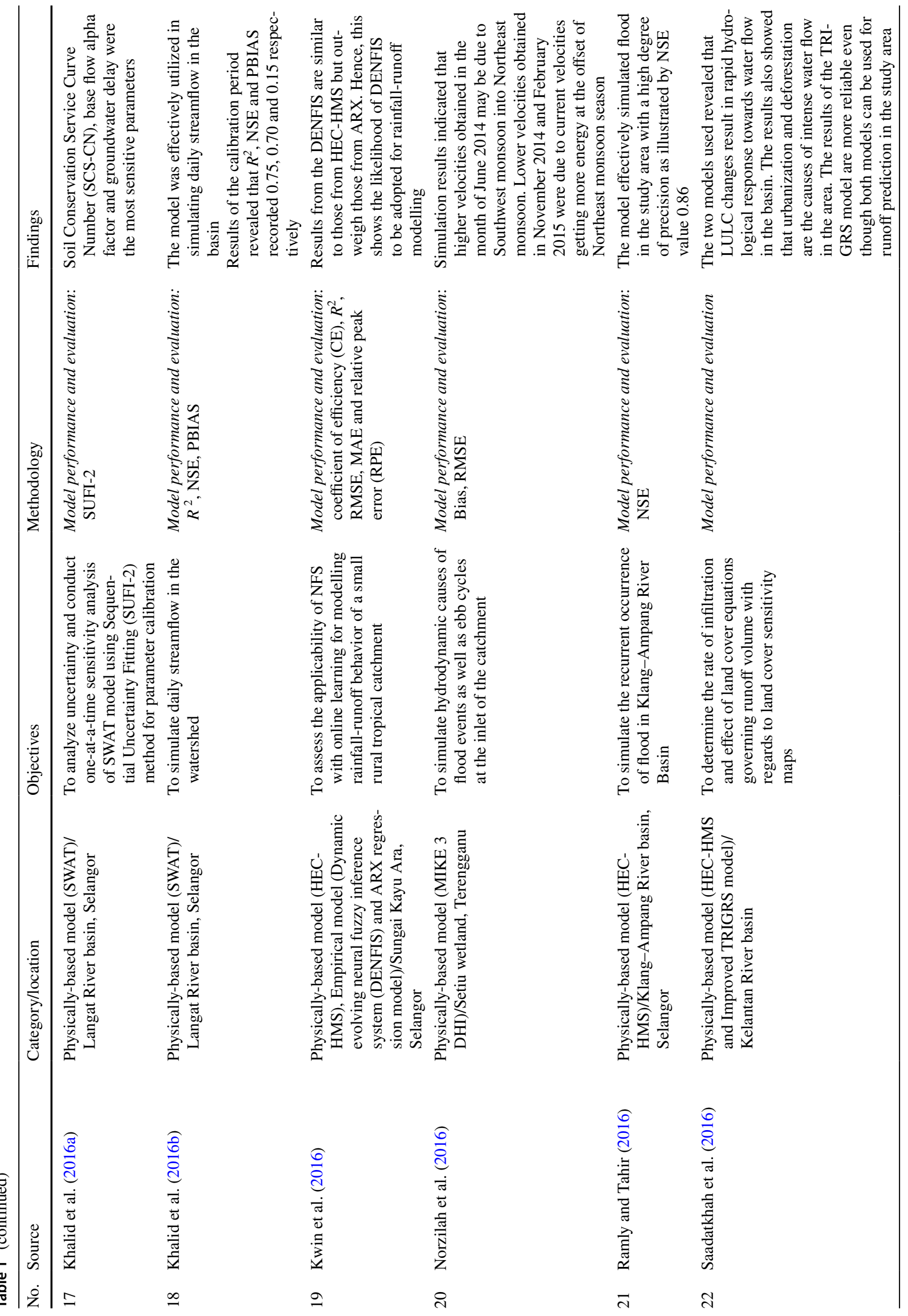




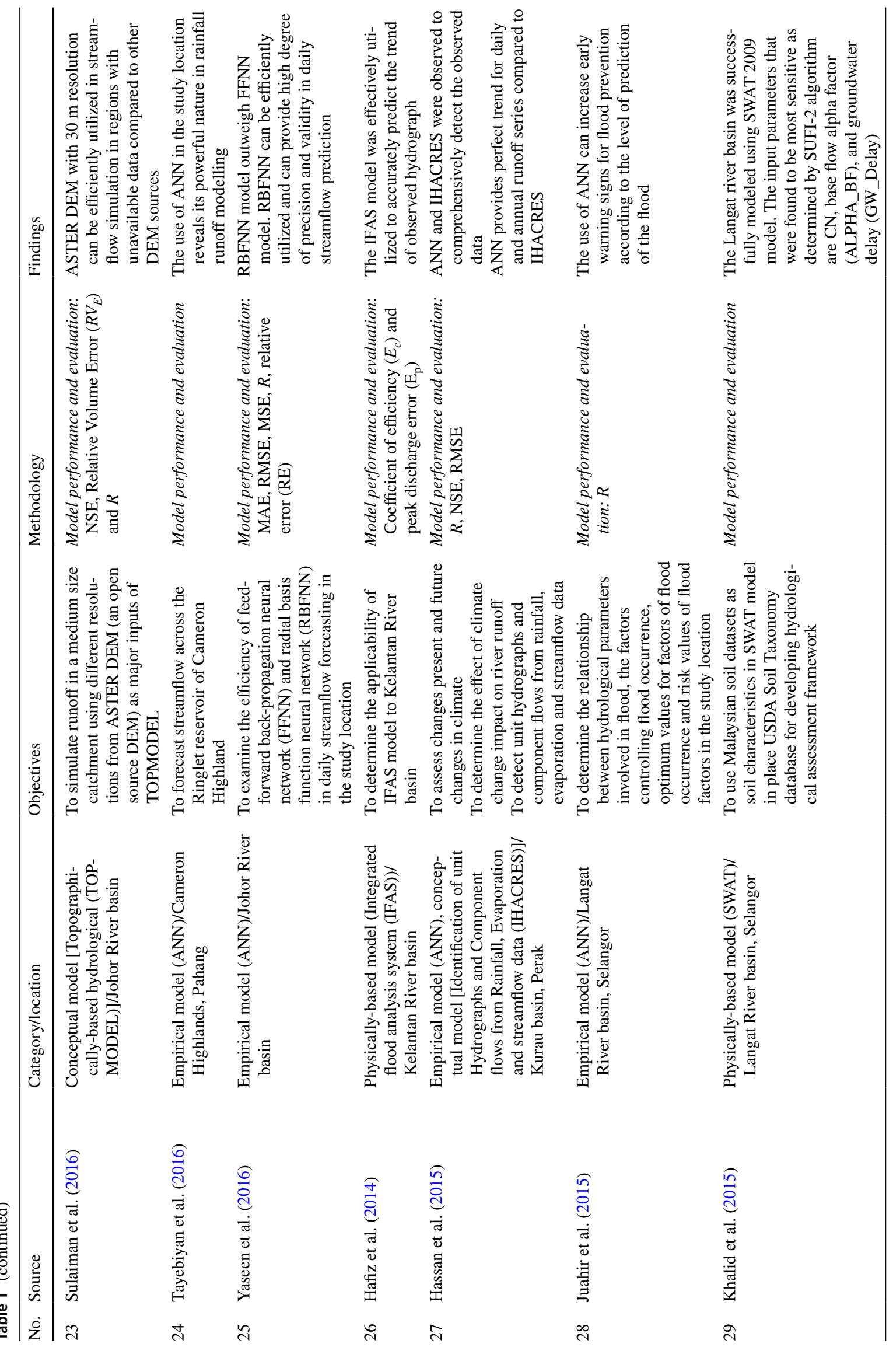




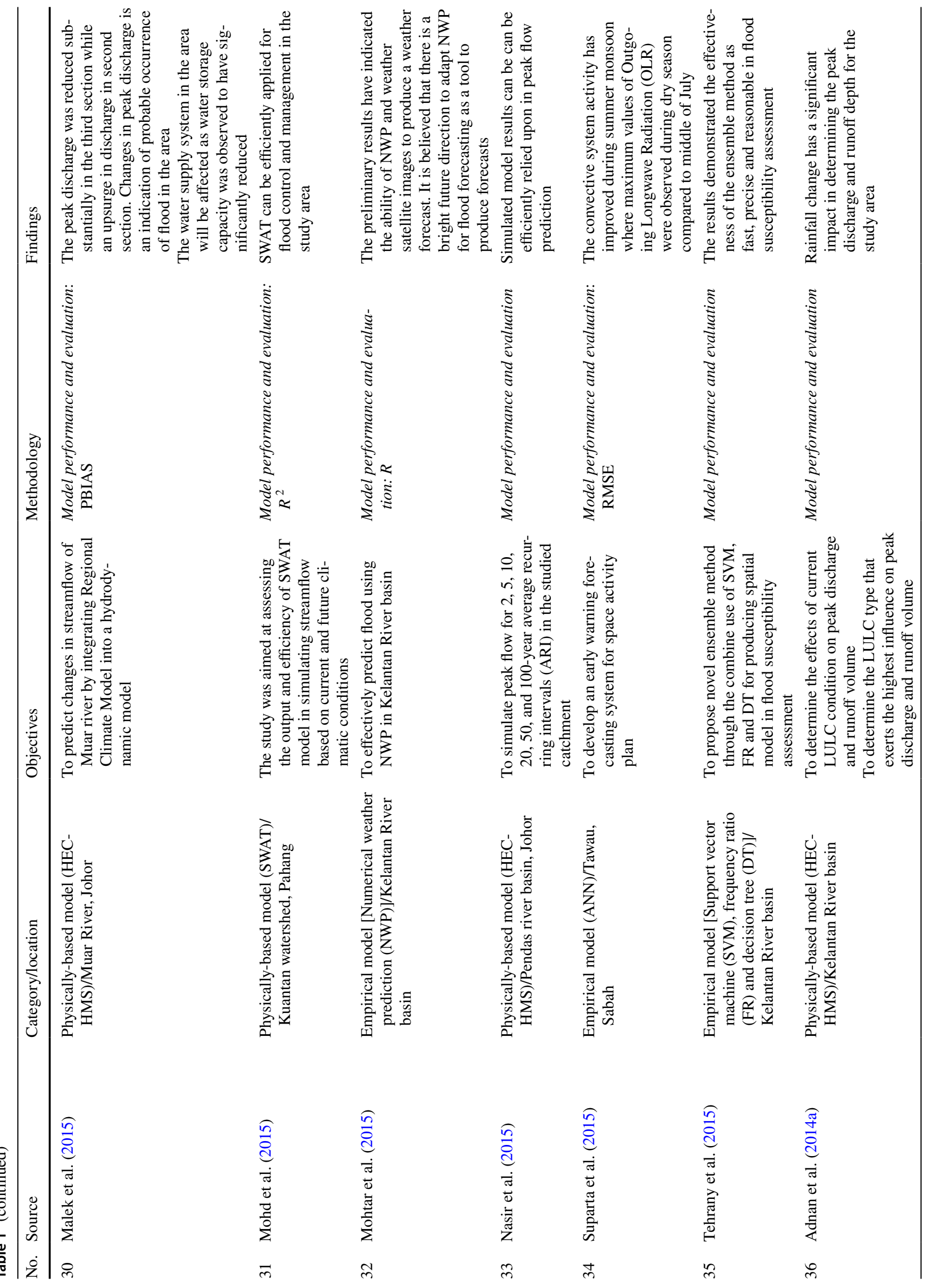




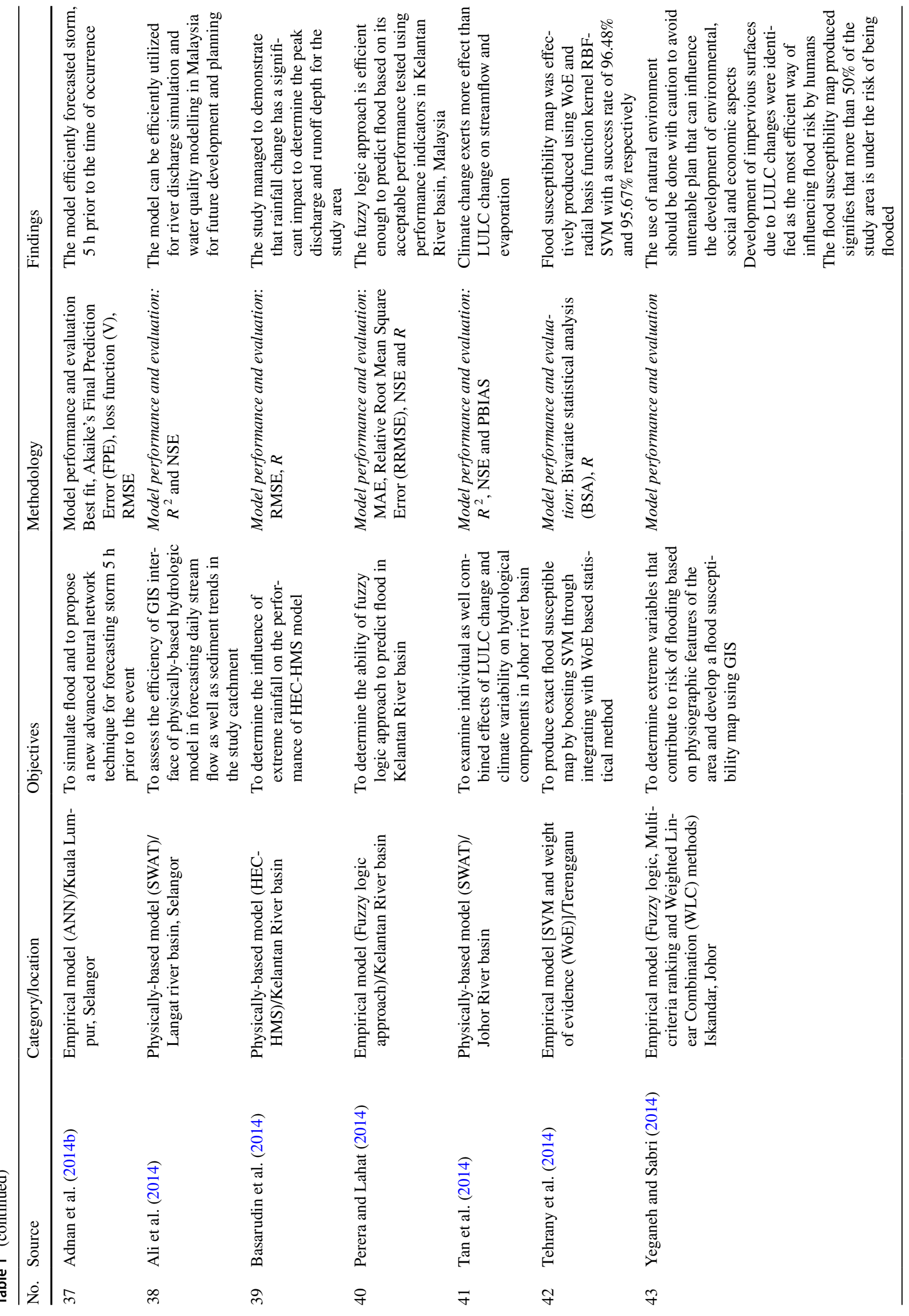




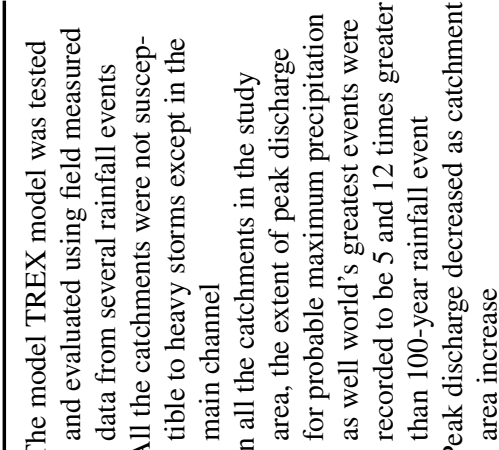

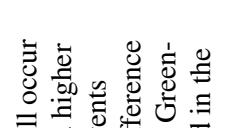

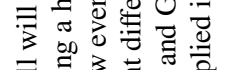

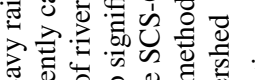

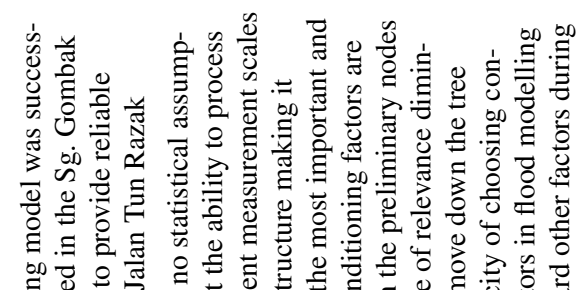

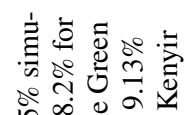

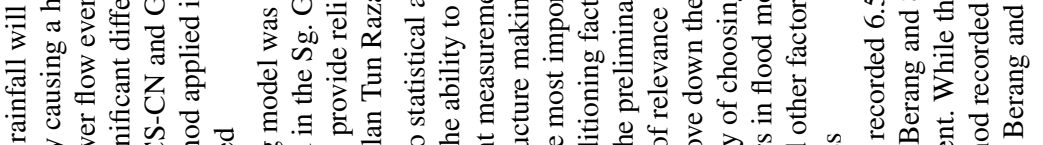

on

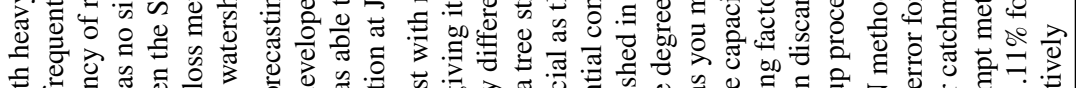

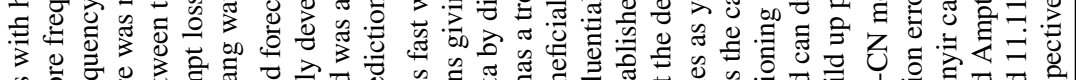

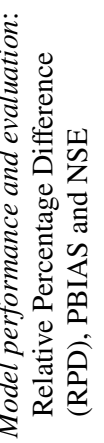

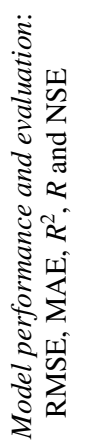

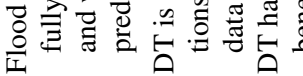

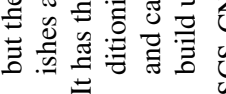

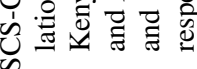

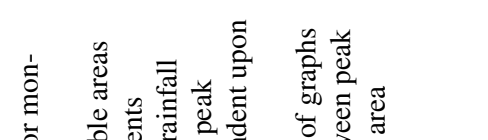

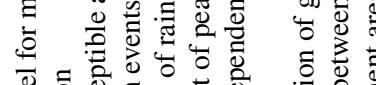

ब .

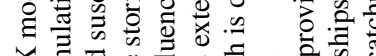

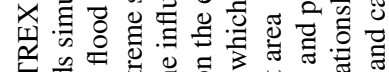

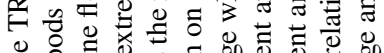

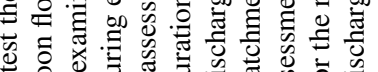

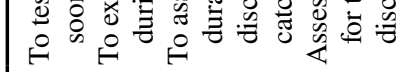

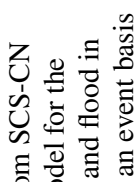

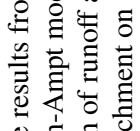

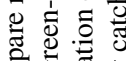

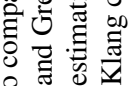

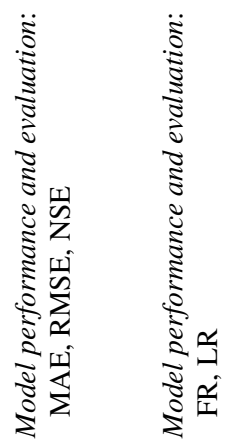

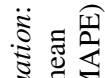

ङ

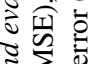

$\Xi \sum$

离离

$\ominus$

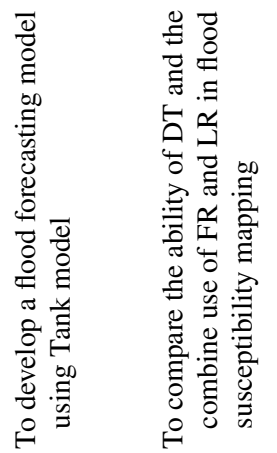

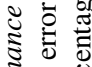

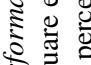

宓

ฐँ ฐี

$\sum_{i}^{\infty}$ ने
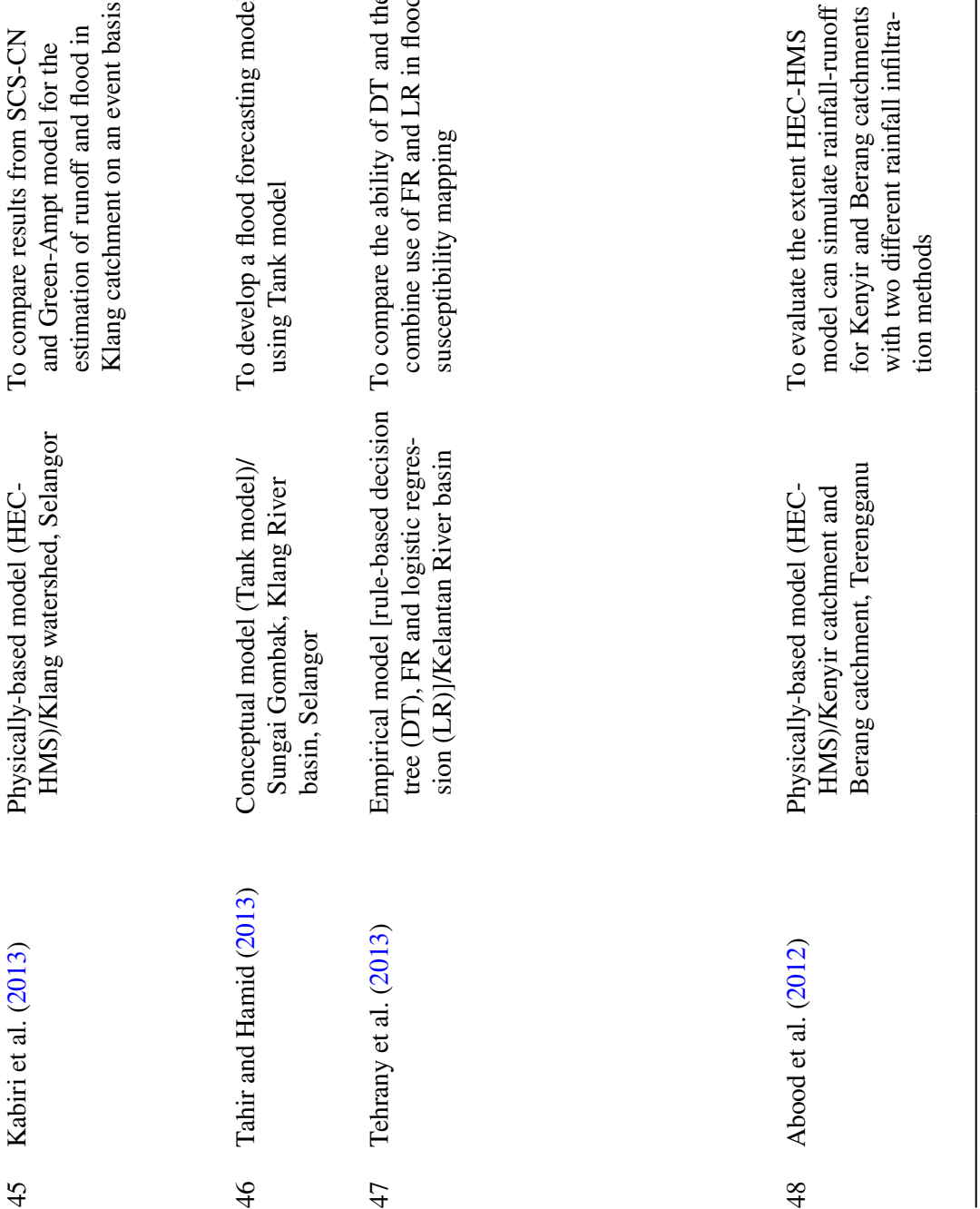


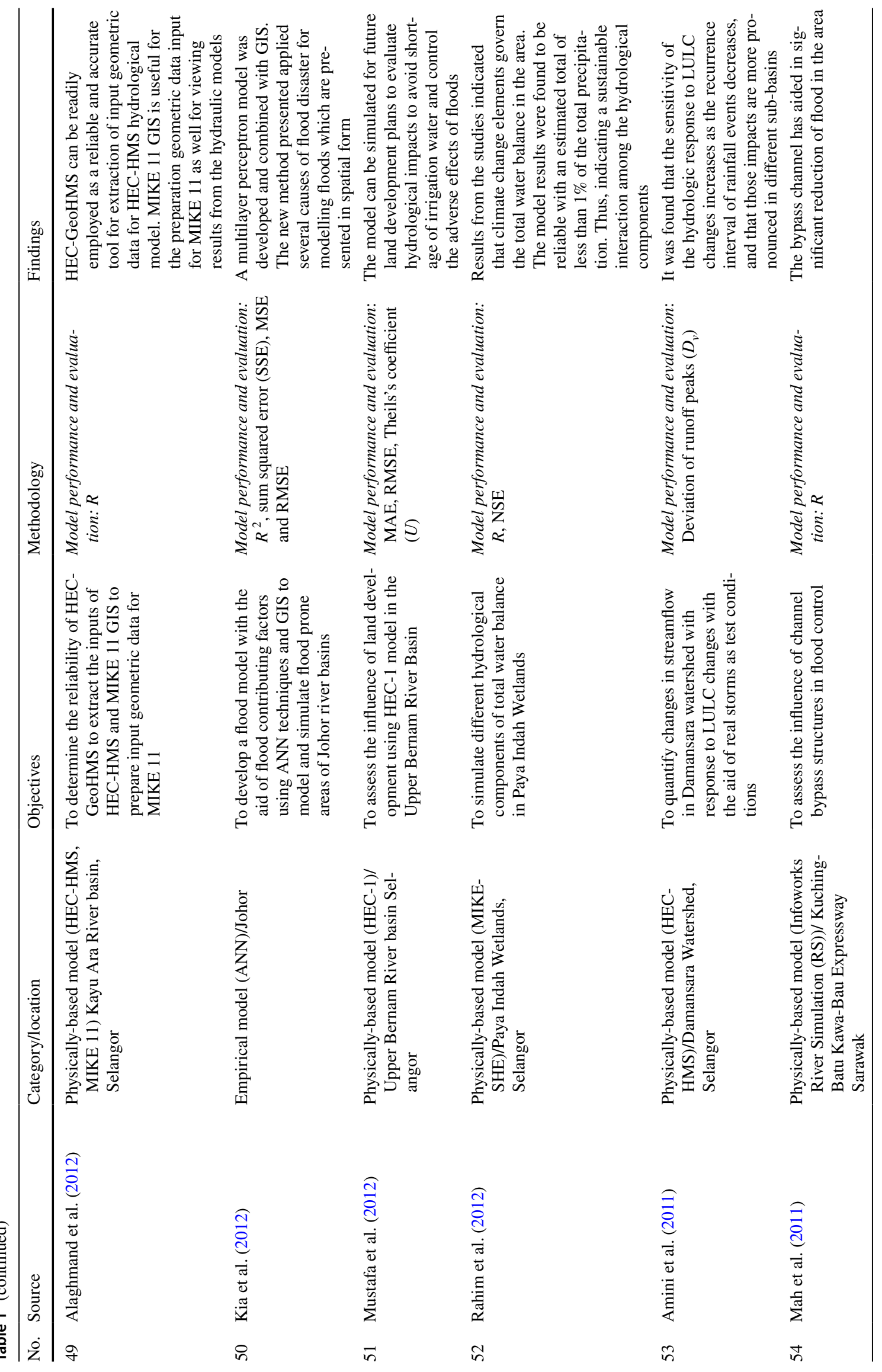




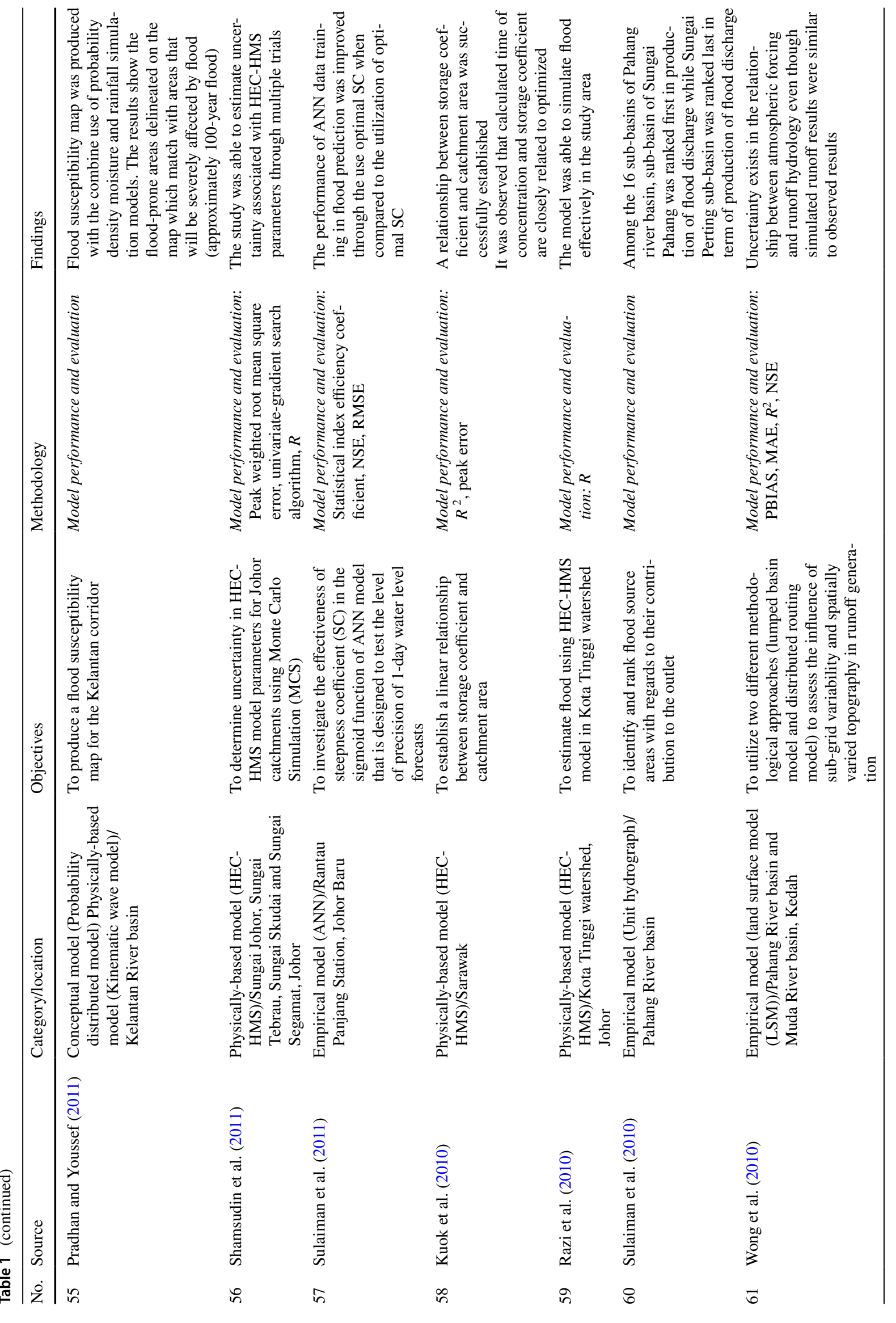




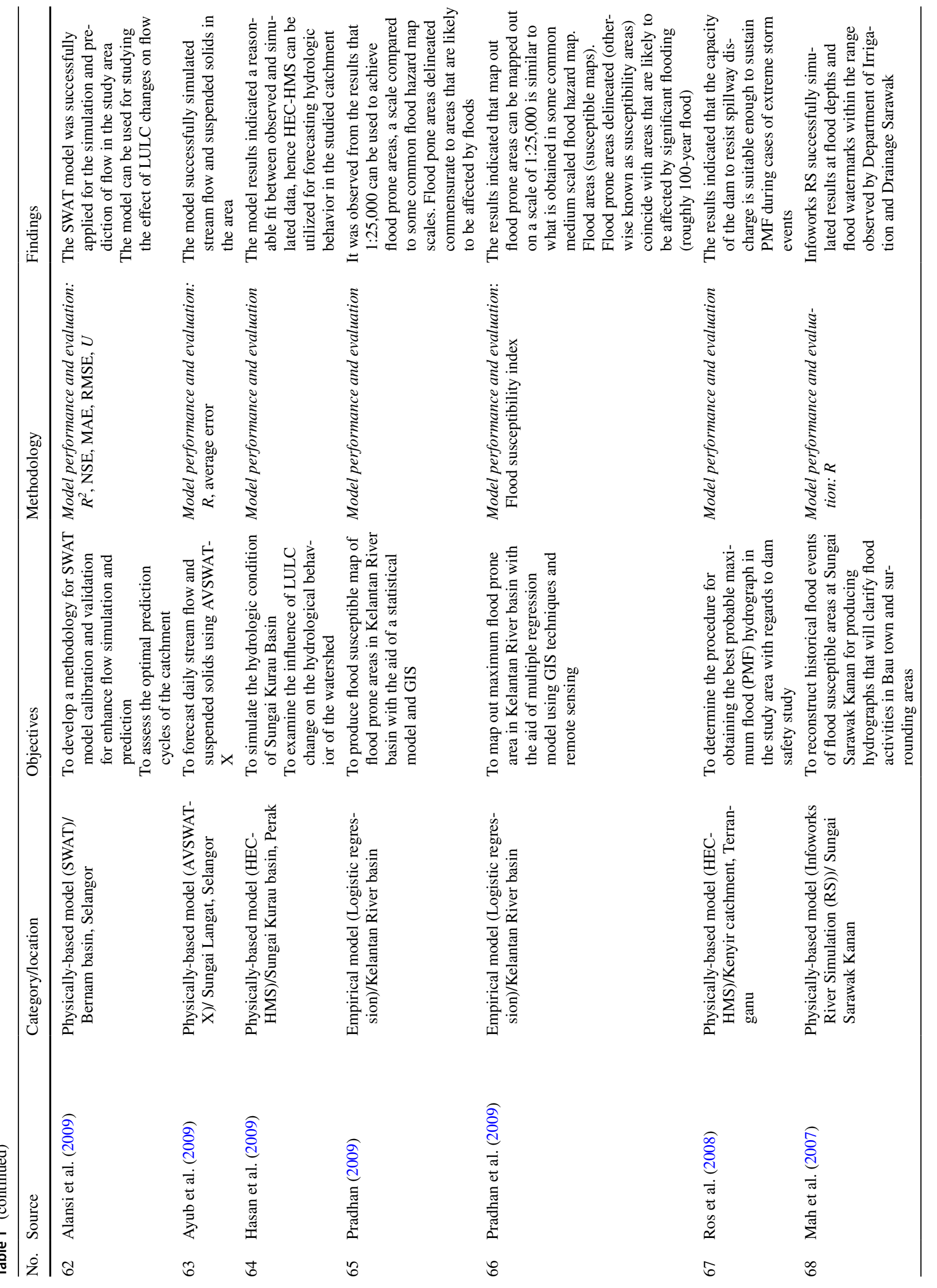


a watershed are stored in the basin model (Verma et al. 2010). HEC-HMS model adopts a concept of semi-distributed modeling by using sub-catchments and channel routing components.

Several researches have been conducted using HEC-HMS model in the river basins of Malaysia for evaluating the hydrologic response of the various catchments (Abdulkareem et al. 2018a, b; Chang et al. 2017; Asmat et al. 2016; Malek et al. 2015; Basarudin et al. 2014; Kabiri et al. 2013). Majority of the hydrological studies reviewed in this study gave attention to long-term streamflow changes in river basins, effect of LULC changes on streamflow and direct runoff as well as the impact of climate change on the hydrological behavior of watersheds (Table 1).

Abdulkareem et al. (2018a) utilized HEC-HMS to determine relative increase or decrease in peak discharge and to assess how each sub-basin contribute to peak discharge and runoff volume under different return periods. The study used two indexes (novel $f a$ index and established $f$ index) to rank sub-basins with regards to their contribution to the outlet. They concluded that the novel $f a$ index is found to rank subbasins better than $f$ index because it considers initial peak discharge per unit area and change in peak discharge per unit area occupied by each sub-basin before ranking. Asmat et al. (2016) applied HEC-HMS model to assess the effect of LULC change in Kelantan, a tropical complex catchment that is under the influence LULC change due to deforestation for logging activities, agriculture and urbanization. They were able to show that direct runoff from developed areas, agricultural regions and grassland areas are more pronounced for flooding events when compared with runoff from other LULC changes in the area. While urbanized areas and areas of low plant density favors the increase of runoff in the monsoon season floods. HEC-HMS model was also applied to Kelantan river basin by Ghorbani et al. (2016). According to their results, flood can be controlled in some sub-basins by applying technical systems, which are dependent on the physiographic features of the sub-basin and its contribution on flood peak. In another study, HEC-HMS model was applied to Muar river, Johor, to detect changes in streamflow of the river (Malek et al. 2015). There results showed changes in peak discharge, which is an indication of probable occurrence of flood in the area. They were also able to detect that the water supply system in the area will be affected as water storage capacity was observed to have significantly reduced (Table 1 ).

Kabiri et al. (2013) used two different infiltration methods SCS-CN and Green-Ampt method in HEC-HMS for the estimation of runoff and flood in Klang catchment on an event basis. They were able to find out that days with heavy rainfall will occur more frequently causing a higher frequency of river flow events. The results also showed that, there was no significant difference between 


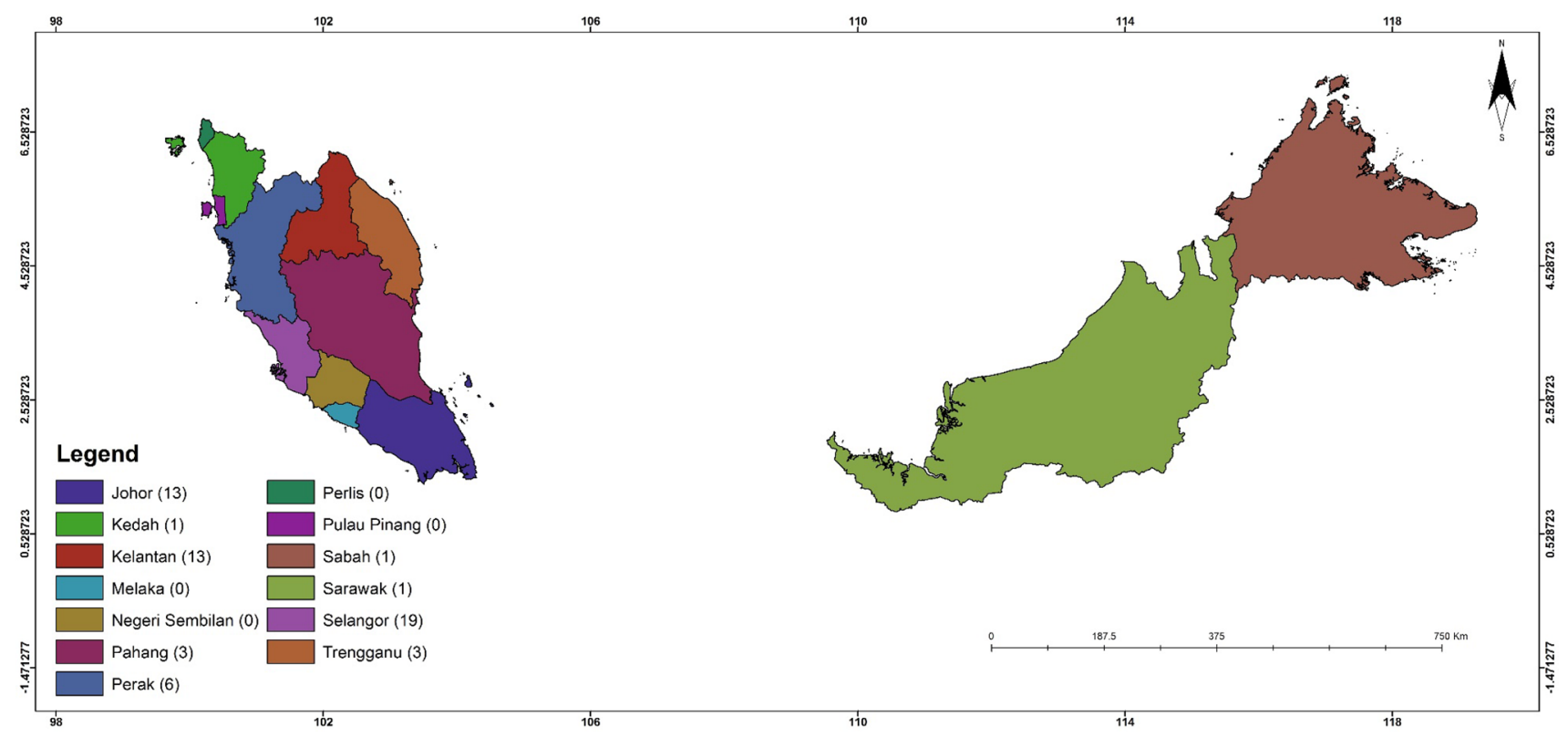

Fig. 4 Map of Malaysia showing spatial distribution of number of hydrological studies across the state

Table 2 Characteristics of Deterministic models

\begin{tabular}{|c|c|c|}
\hline Physically based model & Conceptual model & Empirical model \\
\hline White box model or mechanistic & Grey box model or parametric & Black box model or metric \\
\hline HEC-HMS, MIKESHE, SWAT & TOPMODEL & ANN, unit hydrograph \\
\hline $\begin{array}{l}\text { Spatial distribution driven, assessment of } \\
\text { parameters outlining physiographic feature }\end{array}$ & $\begin{array}{l}\text { Involve reservoir modelling comprise semi- } \\
\text { empirical equations that are physically based }\end{array}$ & $\begin{array}{l}\text { Mathematical equations with values derived } \\
\text { from time series }\end{array}$ \\
\hline $\begin{array}{l}\text { Initial model data required as well as water- } \\
\text { shed morphological features }\end{array}$ & $\begin{array}{l}\text { Parameters are extracted from field data and } \\
\text { calibration }\end{array}$ & $\begin{array}{l}\text { Features and processes of the system are mini- } \\
\text { mally considered }\end{array}$ \\
\hline $\begin{array}{l}\text { Complex model and not easy to use. Require } \\
\text { skills and computational capability }\end{array}$ & Simple and easy to use in computer code & $\begin{array}{l}\text { High degree of forecasting ability, low } \\
\text { explanatory depth }\end{array}$ \\
\hline Challenges with scale related problems & $\begin{array}{l}\text { Large data sets required (hydrological and } \\
\text { meteorological data) }\end{array}$ & Differ from one catchment to the other \\
\hline Valid for several conditions & $\begin{array}{l}\text { Curve fitting as part of the calibration process } \\
\text { giving difficulties in physical interpretation }\end{array}$ & Valid within the boundary of a certain domain \\
\hline
\end{tabular}

the SCS-CN and Green-Ampt loss method applied in the Klang watershed. Abood et al. (2012) also compared SCS-CN and Green-Ampt methods in HEC-HMS in two different catchments (Kenyir and Berang catchments). They also reported no significant difference exist between the two infiltration methods in the two catchments. In another study, uncertainty in HEC-HMS model parameters for Johor catchments using Monte Carlo Simulation (MCS) was determined (Shamsudin et al. 2011). The results of the uncertainty analyses were given in a range of $1.25-4.99 \mathrm{~mm}$ for initial loss, with an average of $153.55 \mathrm{~mm} / \mathrm{h}$. While constant loss rate was reported to have a range of $0.98-299.87 \mathrm{~mm} / \mathrm{h}$ with an average of $153.55 \mathrm{~mm} / \mathrm{h}$. The study was able to estimate uncertainty associated with HEC-HMS parameters through multiple trials. A dam safety study was integrated with HEC-HMS modelling in Kenyir catchment, Terranganu with the aim of determining the procedure for obtaining the best probable maximum flood (PMF) hydrograph (Ros et al. 2008). The results indicated that the capacity of the dam to resist spillway discharge is suitable enough to sustain PMF during cases of extreme storm events. Yusop et al. (2007) utilized HEC-HMS in an oil palm dominated catchment to determine runoff features and outcome of hydrograph modelling. Their simulation showed that peak flow and storm flow volume were moderately correlated with rainfall and the hydrographs were satisfactorily modeled using the HEC-HMS. The efficiency indexes of the calibration and validation exercises are 0.81 and 0.82 , respectively (Table 1). 


\section{SWAT}

Soil water assessment tool (SWAT), is a public domain physically-based model developed to examine and predict the circulation of water and sediment as well as agricultural production with nutrients (Arnold et al. 2005). It has an excellent capability of simulating long-term experiments to facilitate real catchment response (Devi et al. 2015; Khalid et al. 2016). SWAT usually delineate a watershed into smaller sub-basins, which are further separated into hydrologic response units (HRU), LULC, vegetation and soil features. The major input parameters used by the model are daily rainfall, minimum and maximum air temperature, solar radiation, relative air humidity and wind speed. The model has been effectively utilized in Malaysia and from around the world (Devi et al. 2015). Some of the researches conducted in Malaysia using SWAT model include; Dlamini et al. (2017), Khalid et al. (2016a), Khalid et al. (2016b), Mohd et al. (2015), Ali et al. (2014), Tan et al. (2014), Alansi et al. (2009). Most of these studies were conducted with their attention focusing on basin hydrological response, that include river discharge, sediment and nutrient flux as well as effect of LULC change on river discharge on surface runoff and the impact of climate change on sediment.

Dlamini et al. (2017) calibrated and validated SWAT model for streamflow simulation in Bernam river basin, Selangor with data scarcity. They also tested how well the newly improved gridded data established by Wong et al. (2011) using kriging and inverse distance interpolation techniques will be used to simulate SWAT model. They showed that results of the simulation are at par with those from the improved data where $R^{2}$, NSE and PBIAS of $0.67,0.62$ and $-9.4 \%$ were obtained for the calibration process while for the validation, values of $0.62,0.61$ and $-4.2 \%$ were recoded respectively. They also found that the new data sets could be applied in the Bernam catchment, as SWAT model was observed to successfully simulate results with these data sets. In another research, Khalid et al. (2016a) analyzed uncertainty and conducted one-at-a-time sensitivity analysis of SWAT model using sequential uncertainty fitting (SUFI-2) method for parameter calibration in Langat river basin, Selangor. The results showed that soil conservation service curve number (SCS$\mathrm{CN}$ ), base flow alpha factor and groundwater delay were the most sensitive parameters. Furthermore, Khalid et al. (2015), were able to calibrate SWAT model using Malaysian soil datasets as soil characteristics in place of USDA Soil Taxonomy database for developing hydrological assessment framework at Langat river basin, Selangor. Results of the simulation revealed that, SWAT could be efficiently applied for flood control and management in the study area. Mohd et al. (2015) worked with SWAT model by coupling it with statistical climate downscaling tools at Kuantan watershed, Pahang. They found that the model could be efficiently applied for flood control and management in the study area (Table 1 ).

Tan et al. (2014) examined individual as well combined effects of LULC change and climate variability on hydrological components in Johor river basin. They showed that a combination of climate and LULC change effect result in the increase of annual streamflow by $4.40 \%$ and that of evaporation by $1.20 \%$. While the individual effect of climate change elevated streamflow by $4.40 \%$ and that of LULC change by $0.06 \%$ while for evaporation, climate causes an upsurge of $2.20 \%$ and LULC change reduced by $-0.20 \%$ (Table 1 ). In another study, the optimal prediction cycles of the catchment were assessed in Bernam basin, Selangor an irrigated basin for rice granary (Alansi et al. 2009). The study used historical record of 27 years' data (1981-2007), data sets from 1981 to 2004 were utilized for calibration while data sets from 2005 to 2007 were used for model validation and flow prediction. A 50\% reduction in the monthly irrigation water was observed in months when flow is low, this underscore the importance of introducing structured best management practices (BMPs) like ponds to the study location. This will enhance land development plan to manage and control future changes in LULC on flow quantity.

SWAT was applied by Ayub et al. (2009) for hydrological evaluation of Langat River Basin using 1997, 2001, and 2003 historical data to compare the model results. Although the model successfully simulated streamflow and suspended solids in the area. The 2 months (June and July 1997) data used for calibration are not satisfactory enough to describe the hydrological performance of the streamflow in the study area based on long time changes while using a daily time bound hydrological model. The recommended time for describing a watershed appropriately is the use of at least 20 years of nonstop daily historical data (Khalid et al. 2016).

\section{MIKE SHE}

Systeme Hydrologique European (MIKE SHE) is a public domain physically-based model that requires large sets of physical parameters for its calibration (Refsgaard and Storm 1995). It was established based on SHE modeling criteria (Abbott et al. 1986a, b) and it is simple and easy to use. Several processes in the hydrological cycle are being considered by the model e.g. rainfall, evapotranspiration, streamflow, interception, saturated and unsaturated ground water flow. The model can simulate the interaction of both overland and channel water movement as well as their individual flow. Simulation of nutrients, pesticides and sediments and several 
other water quality problems can as well be carried out in large catchments (Devi et al. 2015).

There are several studies in Malaysia that applied MIKE SHE and MIKE related versions (Table 1). For example Goh et al. (2016) used MIKE BASIN a map-based decision support tool to examine probable future water scarcity in Klang river basin, Selangor with regards to climate change. Simulation results from dam level were not alike with observed results for the reservoir model verification. This may be due to data scarcity especially rainfall at the upstream of the dam. Therefore, 18 Global Circulation Models (2046-2065) downscaled projected future rainfall data were utilized for climate change scenario assessment. There results showed that water deficit analysis carried out using 2046-2065 indicated that there will be water unavailability in majority of the months.

Norzilah et al. (2016) used MIKE 3 (uses a technology similar to that of MIKE 21) at Setiu wetland, Terengganu to simulate hydrodynamic causes of flood events as well as ebb cycles at the inlet of the catchment. The results of the simulation indicated that higher velocities obtained in the month of June 2014 might be due to Southwest monsoon into Northeast monsoon. Lower velocities obtained in November 2014 and February 2015 were due to current velocities getting more energy at the offset of Northeast monsoon season. In another research where different hydrological components of total water balance were simulated using MIKE-SHE at Paya Indah Wetlands (Rahim et al. 2012). There have being reported worries on the uncertainty of hydrological behavior of the wetlands to climate change and forest management (Lu et al. 2006). Results from the studies indicated that climate change elements govern the total water balance in the area. The model results were found to be reliable with an estimated total of $>1 \%$ of the total precipitation. Thus, indicating a sustainable interaction among the hydrological components.

\section{Conceptual models}

Conceptual models otherwise known as lumped models are also commonly applied in hydrological modelling. They function with dissimilar but mutually interconnected storages that illustrate physical features in a watershed. Conceptual models operate using a system that accounts for stored moisture contents on a continuous basis. Hydrological behavior description cannot be built upon equations that are meant to be valid for each soil unit, because all model parameters represent an average value of the entire watershed. Thus, the equations will have a physical base even though they are semi-empirical in nature. As such, calibration also becomes a component of assessing model parameters as field data alone cannot be sufficiently used. The availability of hydrological time series data large enough for modelling permits the use of conceptual models for rainfall-runoff simulation. In Malaysia, few researches exist in literature that applied conceptual models to measured hydrological data for streamflow prediction as shown in Table 1.

Sulaiman et al. (2016) applied TOPMODEL (Topographically-based hydrological) in a medium size catchment in Johor river basin for the simulation of runoff using different resolutions from ASTER DEM (an open source DEM) as major inputs of TOPMODEL. The TOPMODEL is a conceptual model designed to capitalize on information that is connected to runoff. It can be applied to a single unit or a multiple unit of sub-basins with the aid of elevation data (usually in grid) for the drainage basin area. The model can also be referred to as variable contributing area conceptual model as its parameters can be measured theoretically. The results showed that ASTER DEM with $30 \mathrm{~m}$ resolution is reasonable in producing topographic index, which is crucial in TOPMODEL and can be efficiently utilized in streamflow simulation in regions with unavailable data compared to other DEM sources. DEM resolutions used in this study ranged from 30 to $300 \mathrm{~m}$ were remarkably observed to influence the topographic index distribution. Additionally, varying the resolution of the DEM exerts a strong influence on the performance of the model.

In a research conducted by Hassan et al. (2015) to determine the effect of climate change impact on river runoff and to detect unit hydrographs and component flows from rainfall, evaporation and streamflow data. The researchers used a conceptual model; IHACRES and an empirical model; ANN at Kurau basin, Perak to achieve these objectives. Although the study did not consider the physical features of the catchment such as topography, soil permeability. The models were able to comprehensively detect the observed data. While ANN provides better trend for daily and annual runoff series compared to IHACRES. Tahir and Hamid (2013) used tank model consisting of four tanks that are similar to actual storage in Sungai Gombak, Klang River basin, Selangor. The hydrological model was developed for flood forecasting in the area. The flood forecasting model was successfully developed in the $\mathrm{Sg}$. Gombak and was able to provide reliable prediction at Jalan Tun Razak. Flood susceptibility map was produced for the Kelantan corridor by Pradhan and Youssef (2011) with the combine use of a conceptual model (probability distributed model) and a physically-based model (kinematic wave model). The study illustrates multiple parameter method for defining flood susceptible areas in the study location carried out in a GIS environment with the aid of multi-criteria decision-making systems. Flood susceptibility map was produced with the combine use of probability density moisture and rainfall simulation models. The results show the flood-prone areas delineated on the 
map match the areas that will be severely affected by flood (approximately 100-year flood).

\section{Empirical models}

Empirical or black box models as they are often called, involved the use of mathematical equations that have been evaluated from concurrent input and output time series and not from physiographic features of a watershed. These models are categorized into three based on their source viz; hydro informatics based, empirical hydrological methods and statistically based methods. The hydro informatics based model is a new class of 'transfer function models' that is currently in use. They are of two types, a group based on neural network, e.g. ANN while the other is based on evolutionary algorithms, e.g. SVM. Empirical hydrological models are the most popular among black box models, e.g. the unit hydrograph model whose principles are mostly applied by most hydrological models (Sherman 1932; Nash 1959). Nowadays most comprehensive models use empirical hydrological models as part of their component. For instance, the unit hydrograph is mostly utilized for river flow routing and linear reservoir to signify groundwater system in conceptual models. Statistically based method used in hydrology were fully developed with the aid of basic statistical theories. They are mathematically more technical than other classes of empirical model, e.g. ARIMA models (Box and Jenkins 1970), The Constrained Linear Systems (CLS) model (Todini and Wallis 1977).

\section{Unit hydrograph}

Unit hydrograph is the hydrograph obtained from one unit excess rainfall that occurs homogenously on a catchment uniformly at a given period. Unit hydrograph has little number of parameters (usually 1-3 but less than 4) which include hydraulic and hydrologic information of the watershed. Physiographic characteristics such as drainage basin area are generally accepted without doubt while other watershed variables are usually estimated (Rabuñal et al. 2007). Unit hydrograph experiments are usually based on two major principles invariance; a hydrograph resulting from runoff in a watershed because of excess rainfall or the total amount of rainfall after infiltration and other losses occur. Superposition; is the hydrograph produced from excess rainfall pattern generated by superimposing unit hydrograph because of distinct quantity of excess rainfall that occurred in each unit (Dooge 1959).

From the review (Table 1), little number of studies were observed that utilized the unit hydrograph for hydrological modelling. Some of them include; the study by Jun et al.
(2016) in Kampung Kasipillay catchment, Selangor conducted with the aim of determining the efficiency and applicability of a flood prediction model in Kampung Kasipillay catchment. The results showed that the model effectively utilized 15 flood events in simulating hydrographs at the study area with a performance error ranging from 2.06 to $5.82 \%$. Sulaiman et al. (2010) integrated the unit hydrograph with flood response approach (Saghafian et al. 2008; Saghafian and Khosroshahi 2005) to identify and rank flood source areas with regards to their contribution to the outlet at Pahang river basin. The results indicated that among the 16 sub-basins of Pahang river basin, sub-basin Sungai Pahang was ranked first in production of flood discharge while Sungai Perting sub-basin was ranked last in terms of production of flood discharge (Table 1).

\section{ANN}

ANN applies generalizations of human cognition or neural biology to process information (Lippmann 1987; Haykin 1999). Commonly used types of ANN include the one with several layers with some neurons on each and interconnected with feed forward connections in other words, withdrawal of one neutron cannot go to the entry of another neutron of the same or succeeding layer and trained with the backpropagation algorithm (Johansson et al. 1991). In Malaysia, the use of ANN in the field of hydrology has recorded tremendous success despite reluctance by some scientist from around the world to utilize this emerging field of hydrology. The black-box nature of ANNs is one of the reasons why some researches from around the globe are unwilling to utilize these models, even though they can be easily be interpreted with some readily available techniques. ANNs has been extensively utilized in Malaysia to model rainfallrunoff relationship in catchments, river flow forecasting, assessment of present and future climatic change, detection of early warning signs for flood prevention among others as summarized in Table 1.

Adenan and Noorani (2016) integrated Chaos approach, ANN, SVM, and LSSVM to forecast river flow direction in Tanjung Tualang station, Perak. The results showed that all the models used provided reasonable flow prediction. In addition, they were able to find out that river flow is deterministic and can easily to be forecasted in the area. They recommended chaos approach as the ideal method for analysis and river flow forecasting for providing information that will be useful to water resources planners. In a different study, Beheshti et al. (2016) predicted rainfall in Johor river basin for the next decade with the aid of two modes of original (free from data preprocessing) and data preprocessing with singular spectrum analysis. They used Centripetal accelerated particle swarm optimization (CAPSO) and 
Gravitational search algorithm (GSA) as free from data preprocessing while Imperialist competitive algorithm (ICA) was utilized as data preprocessing with singular spectrum analysis. It was observed from the results that hybrid learning of multilayer perception (MLP) with CAPSO algorithm gives better rainfall prediction accuracy, small errors and high degree of precision than other algorithms. The use CAPSO has advantages over other algorithms that include; it does not require tuning of any algorithmetic parameter and it illustrates a good performance with testing data. Kwin et al. (2016) integrated a physically-based model (HEC-HMS) and dynamic evolving neural fuzzy inference system (DENFIS) and ARX regression model to assess the applicability of NFS with online learning for modelling rainfall-runoff behavior of a small rural tropical catchment. Results from the DENFIS are similar to those from HEC-HMS but outweigh those from ARX. Hence, this shows the likelihood of DENFIS to be adopted for rainfall-runoff modelling.

The efficiency of feed-forward back-propagation neural network (FFNN) and radial basis function neural network (RBFNN) was tested in daily streamflow forecasting in Johor river basin (Yaseen et al. 2016). The results pointed out that RBFNN model outweigh FFNN model. RBFNN can be efficiently utilized and can provide high degree of precision and validity in daily streamflow prediction. Tehrany et al. (2015) carried out a study in Kelantan river basin aimed at proposing novel ensemble method through the combine use of SVM, FR and DT for producing spatial model in flood susceptibility assessment. They were able to prove that the individual use of statistical and other machine learning methods is not sufficient for flood susceptibility assessment. The results demonstrated the effectiveness of the ensemble methods as fast, precise and reasonable in flood susceptibility assessment. Fuzzy logic was applied at Iskandar, Johor to determine extreme variables that contribute to risk of flooding based on physiographic features of the area and develop a flood susceptibility map using GIS (Yeganeh and Sabri 2014). From the study, it was found out that the use of natural environment should be done with caution to avoid untenable plan that can influence the development of environmental, social and economic aspects. Development of impervious surfaces because of LULC changes were identified as the most efficient way of influencing flood risk by humans. The flood susceptibility map produced signifies that more than $50 \%$ of the study area is under the risk of being flooded.

\section{Model performance and evaluation}

The use of modeling tools in water resources management is on the rise which is aimed at predicting the possible future changes in climate, land use change as well as land and crop management practices on the quantity and quality of land and water resources (Moriasi and Wilson 2012). Yet, the ability of these models to make predictions accurately is still needed to be verified using proper model validation techniques (Bathurst et al. 2004). Although, the choice of appropriate validation technique to be used for a hydrologic model is still a topic of research on its own. It should however be noted that no general procedure exists for the validation of models in the literature. In view of this, numerous modelers are of different views as to how validation should be carried out and reported for facilitating the peer-review process and the ability to bear legal scrutiny (Santhi et al. 2001; Engel and Flanagan 2006; Jakeman et al. 2006; Moriasi et al. 2007; Moriasi and Wilson 2012).

Agreement between observed and simulated values are evaluated either using graphical and statistical methods during hydrological model calibration and validation. Graphical method is the oldest and easiest method to use. It can be used by comparing observed and simulated time to peak, peak discharge, rising and falling limb (Green and Stephenson 1986; Legates and McCabe 1999). The use of graphical method is sometimes difficult especially when unequal but similar observed and simulated values are involved (Green and Stephenson 1986). Statistical method uses numerical values to test the level of agreement between observe and simulated time to peak, peak discharge, and volume of flow. Statistical measures are used to describe the validity of a model for a particular application and this may guide the modelers to choose the most appropriate type of model for the application in question (Bellocchi et al. 2010). For any hydrologic model to be applied successfully, calibration and validation processes are crucial. This is normally dependent upon the technical capability of the hydrological model, technical skills of the operator as well as the quality of input data. For most, if not all, hydrologic models calibration is an interactive procedure for parameter evaluation and improvement. It plays a vital role in hydrologic modeling by reducing uncertainties in model predictions. In reality, model validation is an extension of the calibration process. Normally in hydrology, calibration and validation are carried out by comparing and finding the relationship between simulated and observed values.

In this review, majority of the hydrological modelling studies utilized one or more statistical method of evaluating model performance except in some few cases where model evaluation criteria was not clearly stated (Table 1). Of the 70 papers reviewed in this study, 16 did not specify the type of model evaluation technique they used in validating their studies, 17 used only one method while 37 used two or more methods. The use of NSE along with other methods as a model evaluation criterion is the highest with a total percentage use of $27 \%$ while $R$ and RMSE came second with a percentage use $24 \%$ each. $R^{2}(20 \%)$ was recorded 
as the third most widely used model evaluation criteria in Malaysia; MAE is fourth with $16 \%$ while PBIAS is the least method use with $11 \%$.

Jun et al. (2016) used performance error only, Ramly and Tahir (2016) employed $R$ only, Malek et al. (2015) applied only PBIAS. In some studies, two or more statistical measures were applied e.g. Adenan and Noorani (2016) evaluated their models with $R$ and RMSE for evaluating their hydrological model. $\mathrm{WB}_{\mathrm{er}}, R$ and NSE were employed by Goh et al. (2016) in testing the performance of their model. Kwin et al. (2016) applied CE, $R^{2}$, RMSE, MAE and RPE for the validation of HEC-HMS, DENFIS and ARX regression model. Other studies did not clearly state the type of model performance and evaluation used, e.g. Abdulkareem et al. (2018a), Asmat et al. (2016), Ghorbani et al. (2016), Khalid et al. (2015), Nasir et al. (2015), Adnan et al. (2014a), Sulaiman et al. (2010) etc. This lack of clear evaluation criteria by some studies may be due to absence of general procedure for validation of models in the literature. As numerous modelers are of different views as to how validation should be carried out and reported for facilitating the peer-review process and the ability to bear legal scrutiny (Santhi et al. 2001; Engel and Flanagan 2006; Jakeman et al. 2006; Moriasi et al. 2007; Moriasi and Wilson 2012). In addition, the use of visual comparison (Saadatkhah et al. 2016) between simulated and observed data as well as judgement based on experience of the modeler are also considered significant by hydrologists for evaluating model reliability and performance. Among the statistical methods commonly utilized in Malaysia for hydrological model performance and evaluation, $R, R^{2}$, NSE, RMSE, MAE and PBIAS were discussed in this review as they are utilized in by different researchers.

\section{Correlation coefficient $(R)$}

$R$ is sometimes mistaken with $R^{2}$. They are both used in evaluating the performance of hydrological models. The Pearson correlation is the most commonly used measure of statistical association. It provides numerical estimate of the statistical co-variation between measured and simulated data (Addiscott and Whitmore 1987). The procedure is presented in Eq. (1);

$R=\frac{\sum_{i=1}^{N}\left(Q_{O b s-} \bar{Q}_{O b s}\right)\left(Q_{s i m-} \bar{Q}_{\text {sim }}\right)}{\sqrt{ } \sum_{i=1}^{N}\left(Q_{O b s-} \bar{Q}_{O b s}\right)^{2}\left(Q_{\text {sim- }} \bar{Q}_{\text {sim }}\right)^{2}}$

where $Q_{\text {Sim }}$ is the simulated discharge at time $t=i, Q_{O b s}$ is the observed discharge at time $t=i, \bar{Q}_{\text {sim }}$ is the average simulated discharge $\bar{Q}_{O b s}$ is the average observed discharge; $N$ is the number of observations. Some scientists are of the view that correlation coefficient should not be used solely as a measure of performance (Fox 1981; Willmott 1982; Abdulkareem et al. 2018c, d). As its degree of assessing performance does not rely on the precision of estimates. This is because correlation between two unequal measurements can be high while a low correlation value may be obtained from measurements with small differences. As such, the use of nonparametric correlation such as concordance, Spearman and Kendall's coefficients are also advocated for model evaluation purposes (Press et al. 1992; Dhanoa et al. 1999; Agresti 2002). In Malaysia, several hydrological studies were conducted that utilized $R$ as a measure for testing the validity of their hydrological models. Example of such researches include; Adenan and Noorani (2016) while working on Chaos approach, ARIMA, ANN, support vector SVM and LSSVM at Tanjung Tualang station, Perak. Beheshti et al. (2016) on ANN in Johor river basin. Goh et al. (2016) on a physically-based model (MIKE BASIN) in Klang river basin, Selangor. Correlation coefficient was applied to a validate two hydrological models, one empirical (ANN) and one conceptual (IHACRES) in Kurau basin, Perak (Hassan et al. 2015).

\section{Coefficient of determination $\left(R^{2}\right)$}

This can be described as the square of correlation coefficient (Krause et al. 2005). The equation representing $R^{2}$ is presented in the following equation;

$R^{2}=\frac{\sum_{i=1}^{N}\left(Q_{O b s-} \bar{Q}_{O b s}\right)\left(Q_{s i m-} \bar{Q}_{s i m}\right)}{\sqrt{ } \sum_{i=1}^{N}\left(Q_{O b s-} \bar{Q}_{O b s}\right)\left(Q_{s i m-} \bar{Q}_{s i m}\right)}$

$R^{2}$ values range from 0 to 1 , which illustrates how the distributed observed variables are described by the simulation. Simulated values equal to 1 represent a perfect distribution between observed and simulated model values, while values equal to 0 signifies no correlation. One major disadvantage of $R^{2}$ is that, there will be ambiguity in the results if the model underestimate or overestimate the results (Krause et al. 2005). Although this can be easily sorted out comparing visually the observed and simulated results (Nejadhashemi et al. 2011).

Just like $R$, several hydrological studies conducted in Malaysia utilized $R^{2}$ as a statistical measure for model validation (Table 1). Ab Razak et al. (2016) applied $R^{2}$ along with MAPE and ACAIC in validating ARIMA model in Segamat river basin, Johor. Mohd et al. (2015) while working in Kuantan watershed, Pahang utilized $R^{2}$ as the only statistical measure in validating a physically-based model (SWAT). $R^{2}$ was used in Langat river basin, Selangor to validate SWAT model for a study aimed at assessing the efficiency of GIS interface of the model in forecasting daily stream flow and sediment trends 
(Ali et al. 2014). Kabiri et al. (2013) used both $R^{2}$ and $R$ in evaluating HEC-HMS model at a semi-urban catchment. Kuok et al. (2010) utilized R2 along with peak error in calibrating and validating HEC-HMS model they used in developing a relationship between storage coefficient and catchment area.

\section{Nash-Sutcliffe efficiency (NSE)}

Nash-Sutcliffe efficiency (Nash and Sutcliffe 1970) is the commonest and highly reliable method for evaluating the analytical power of hydrological models. It is represented by Eq. 3. NSE values ranges between 0 and 1 . A perfect fit is denoted by the value 1 while 0 denotes a poor fit. According to Andersen et al. (2001), NSE values between 0.50 and 0.95 represent good simulation result. It is worth mentioning that a subset of these statistics has been and is being used in the studies on model evaluation with the use of NSE as the commonest tool in most studies (McCuen et al. 2006).

$$
N S E=1-\frac{\sum_{i=1}^{N}\left(Q_{i O b s-} Q_{i S i m}\right)^{2}}{\sum_{i=1}^{N}\left(Q_{i O b s} \bar{Q}_{i O b s}\right)^{2}}
$$

The reliable nature of NSE in evaluating hydrological models makes it a very common tool in Malaysia for assessing hydrological models depending on whether the model in question is physically-based, empirical or conceptual (Table 1). e.g. Romaly et al. (2018) used NSE on HEC-HMS (physicallybased model) to evaluate a study conducted with the aim of simulating 2011 flood peak that will be used to generate flood maps of Segamat 2011 flood. Beheshti et al. (2016) used NSE on ANN (an empirical model) to predict rainfall in Johor river basin for the next decade. A physically-based model (HECHMS) was validated with NSE by Ramly and Tahir (2016) while working in Klang-Ampang River basin, Selangor. Sulaiman et al. (2016) evaluated the performance of a conceptual model (TOPMODEL) to simulate runoff on a medium size catchment using different resolutions from ASTER DEM in Johor river basin. In another research that integrated an empirical model (ANN) and a conceptual model (IHACRES) in Kurau basin, Perak, NSE was utilized for the validating both models (Hassan et al. 2015). Perera and Lahat (2014) simulated and validated a Fuzzy logic approach (empirical model) with the NSE for determining the ability of the model to predict flood in Kelantan river basin.

\section{Root mean square error (RMSE)}

In order to have a positive evaluation result, careful selection of variables for RMSE was recommended by Moriasi et al. (2007). This is a prerequisite given by Eq. 4, that measures the level of fitness between the model simulated data and the observed data. The values normally used are peak discharge, time to peak and total volume. Other parameters can also be used depending on the model in question and the desired objective.

$R M S E=\left(\frac{\sum_{i=1}^{N}\left(Q_{i O b s}-Q_{i S i m}\right)^{2}}{N}\right)^{\frac{1}{2}}$

The use of RMSE cut across both physically-based, conceptual and empirical models in Malaysia as highlighted in Table 1 (e.g. Norzilah et al. 2016; Yaseen et al. 2016; Hassan et al. 2015; Adnan et al. 2014b; Tahir and Hamid 2013, etc.).

\section{Mean absolute error (MAE)}

MAE given by Eq. 5, is used in determining the global goodness of fit of simulated error (the difference between the observed data and the model predicted output). MAE values of $O$ indicate a perfect fit.

$M A E=\frac{\sum_{i}^{N}\left|Q_{i O b s}-Q_{i S i m}\right|}{N}$

Mean absolute error is a type of statistical measure utilized by hydrologists for hydrological validation. Table 1 shows some of the researches that applied MAE for evaluating their hydrological models e.g. Adnan and Atkinson (2018) applied MAE along with other model evaluation criteria to examine changes that are responsible for variations in peak flow using 1988 and 2004 data. MAE was also applied as one of the statistical measures evaluating a research involving 3 different models; physically-based model (HEC-HMS), empirical model DENFIS and ARX regression model at Sungai Kayu Ara, Selangor (Kwin et al. 2016). Mustafa et al. (2012) used MAE to validate a physically-based model (HEC-1) at Upper Bernam River basin Selangor. LSM model was evaluated with MAE in Pahang River basin and Muda River basin for a study aimed at assessing the influence of sub-grid variability and spatially varied topography in runoff generation (Wong et al. 2010). Alansi et al. (2009) applied MAE for evaluating a SWAT model in Bernam basin, Selangor.

\section{Percent BIAS (PBIAS)}

Gupta et al. (1999) reported that PBIAS is a type of statistical error analysis that quantifies the likelihood of simulated model values to overestimate or underestimate the observed data. PBIAS can be calculated using the following equation;

$$
\text { PBIAS }=\left(\frac{\sum_{i=1}^{N}\left(Q_{i O b s}-Q_{i S i m}\right)^{2}}{\sum_{i=1}^{N} Q_{i O b s}}\right) \times 100
$$


Values of PBIAS can either be positive or negative. Positive value indicated that simulated values have underestimated observed values (peak discharge, time to peak or volume of flow). While a positive PBIAS value is an indication of overestimation of observed values by the simulated values. PBIAS values equal to zero indicated that the model perfectly simulated the results given rise to the same values of both observed and simulated values. Application of PBIAS for evaluating hydrological model performance in Malaysia is not as extensive as that of the measures of performance. As only a handful of researches were observed to utilize this criteria (Dlamini et al. 2017; Malek et al. 2015; Tan et al. 2014; Abdullah 2013; Wong et al. 2010).

\section{Conclusion}

A review of hydrological modelling studies in Malaysia was conducted in this study. The objectives, hydrological model utilized in each studies and findings were identified, summarized and presented in a tabular form. The major hydrological models used in Malaysia were discussed along with their advantages and major set-backs. From the review, it was found that, most hydrological studies focused on simulating streamflow in one river basin or the other. The results showed that $65 \%$ of the studies conducted used physicallybased models, $37 \%$ used empirical models while $6 \%$ used conceptual models. Of the $65 \%$ of physically-based modelling studies, $60 \%$ utilized HEC-HMS an open source models, 20\% used SWAT (public domain model), 9\% applied MIKESHE, MIKE 11 and MIKE 22, while Infoworks RS occupied $7 \%$ whereas TREX and IFAS occupy $2 \%$ each. Thus, indicating preference for open access models in Malaysia. In the case of empirical models, $46 \%$ from the total of empirical researches applied ANN, 13\% used LR, while Fuzzy logic, UH, ARIMA, SVM contributed $8 \%$ each whereas the remaining proportion is occupied by NWP, LSM, FR, DT and WoE.

Majority of the hydrological modelling studies utilized one statistical method or the other for evaluating hydrological model performance except in some few cases where model evaluation criteria was not clearly stated. Of the 70 papers reviewed in this study, 16 did not specify the type of model evaluation technique they used in validating their studies, 17 used only one method while 37 used two or more methods. The use of NSE along with other methods as a model evaluation criterion is the highest with a total percentage use of $27 \%$ while $R$ and RMSE are second with a percentage use $24 \%$ each. $R^{2}(20 \%)$ was recorded as the third most widely used model evaluation criteria in Malaysia, MAE came fourth with $16 \%$ while PBIAS is the least with $11 \%$.
Selangor state recorded a total 21 hydrological studies from the review (e.g. Chang et al. 2017; Dlamini et al. 2017; Goh et al. 2016; Khalid et al. 2015). This could be attributed to numerous rivers in the state such as Sungai Kayu Aru River basin, Upper Bernam River basin, Klang, Langat River who's changing hydrological behaviors with response to LULC changes and climate change need to be regularly monitored. Johor and Kelantan were ranked second each with 17 hydrological researches in this review. This may be due to high incidence of flood disasters in Kelantan as reported by several authors (Tehrany et al. 2014; Kia et al. 2012; Pradhan and Youssef 2011). Sabah and Sarawak ranked third with 5 hydrological studies reviewed in this study. Pahang recorded 4 researches, Perak and Terengganu came fifth with 3 researches each. Two hydrological studies were recorded in Kedah.

In conclusion, for any modeler to conduct a hydrological modelling study, it will be necessary for them to identify the problems and objectives of the intended research as well as resources available. This will help them in choosing the best model and evaluation techniques for their project to overcome the limitations attached to each. In addition, the need for an integrated modeling approach (using two or more models for a project) is strongly advocated by this study. This will help modelers to compare results from different model types to make a better prediction of streamflow changes that will be useful to water resources planners and decision makers.

\section{References}

Ab Razak NH, Aris AZ, Ramli MF, Looi LJ, Juahir H (2016) Temporal flood incidence forecasting for Segamat River (Malaysia) using autoregressive integrated moving average modelling. J Flood Risk Manag. https://doi.org/10.1111/jfr3.12258

Abbott MB, Bathurst JC, Cunge JA, O'Connell PE, Rasmussen J (1986a) An introduction to the European Hydrological System-Systeme Hydrologique Europeen, "SHE", 1: history and philosophy of a physically-based, distributed modelling system. J Hydrol 87:45-59

Abbott MB, Bathurst JC, Cunge JA, O'connell PE, Rasmussen J (1986b) An introduction to the European Hydrological SystemSysteme Hydrologique Europeen, "SHE”, 2: Structure of a physically-based, distributed modelling system. J Hydrol 87:61-77

Abdulkareem JH, Pradhan B, Sulaiman WNA, Jamil NR (2017) Prediction of spatial soil loss impacted by long-term land-use/landcover change in a tropical watershed. Geosci Front. https://doi. org/10.1016/j.gsf.2017.10.010

Abdulkareem JH, Sulaiman WNA, Pradhan B, NR Jamil (2018a) Relationship between design floods and land use land cover (LULC) changes in a tropical complex catchment. Arab J Geosci 11:376. https://doi.org/10.1007/s12517-018-3702-4

Abdulkareem JH, Pradhan B, Sulaiman WNA, Jamil NR (2018b) Quantification of runoff as influenced by morphometric characteristics in a rural complex catchment. Earth Syst Environ 2:145-162. https://doi.org/10.1007/s41748-018-0043-0 
Abdulkareem JH, Sulaiman WNA, Pradhan B, Jamil NR (2018c) Long-term hydrologic impact assessment of non-point source pollution measured through land use/land cover (LULC) changes in a tropical complex catchment. Earth Syst Environ. https://doi.org/10.1007/s41748-018-0042-1

Abdulkareem JH, Pradhan B, Sulaiman WNA, Jamil NR (2018d) Long-term runoff dynamics assessment measured through land use/cover (LULC) changes in a tropical complex catchment. Environ Syst. https://doi.org/10.1007/s10669-018-9696-3

Abdullah J (2013) Distributed Runoff Simulation of Extreme Monsoon Rainstorms in Malaysia Using TREX. Dissertation Colorado State University Fort Collins, Colorado

Abood MM, Mohammed TA, Ghazali AH, Mahmud AR, Sidek LM (2012) Impact of infiltration methods on the accuracy of rainfall-runoff simulation. Appl Sci Eng Tech 4:1708-1713. https://www.scopus.com/inward/record.uri?eid=2-s2.084862063367\& partnerID=40\&md5=a9fb9185b81a9fe7328e 7b44b5afea25. Accessed 12 Mar 2017

Addiscott TM, Whitmore AP (1987) Computer simulation of changes in soil mineral nitrogen and crop nitrogen during autumn, winter and spring. J Agric Sci 109:141-157

Adenan NH, Noorani MSM (2016) Multiple time-scales nonlinear prediction of river flow using chaos approach. J Technol 78:1-7

Adnan NA, Atkinson PM (2018) Disentangling the effects of longterm changes in precipitation and land use on hydrological response in a monsoonal catchment. J Flood Risk Manag 11:1063-1077

Adnan NA, Basarudin Z, Che Omar N (2014a) Variation in hydrological responses estimation simulations due to land use changes. In: International conference on civil, biological and environmental engineering (CBEE), Istanbul, Turkey, pp. 27-28

Adnan R, Samad AM, Zain ZM, Ruslan FA (2014b) 5 hours flood prediction modeling using improved NNARX structure: case study Kuala Lumpur. In: Proceedings of the 2014 IEEE 4th international conference on system engineering and technology, ICSET 2014, pp 5-9. https://doi.org/10.1109/ICSEngT.2014.7111799

Agresti A (2002) Categorical data analysis (vol 2). Wiley, New York

Alaghmand S, Abdullah R, Abustan I, Said MA, Vosoogh B (2012) GIS-based river basin flood modelling using HEC-HMS and MIKE 11-Kayu Ara River basin, Malaysia. J Environ Hydrol 20:1-16

Alam MJ, Meah MA, Noor MS (2011) Numerical modeling of ground water flow and the effect of boundary conditions for the hsieh aquifer. Asian J Math Stat 4:33-44

Alansi AW, Amin MSM, Abdul Halim G, Shafri HZM, Aimrun W (2009) Validation of SWAT model for stream flow simulation and forecasting in Upper Bernam humid tropical river basin, Malaysia. Hydrol Earth Syst Sci 6:7581-7609. https://doi.org/10.5194/ hessd-6-7581-2009

Ali MF, Rahman NFA, Khalid K (2014) Discharge assessment by using integrated hydrologic model for environmental technology development. Adv Mat Res 911:378-382. http://doi.org/10.4028/ www.scientific.net/AMR.911.378

Amini A, Ali TM, Ghazali AHB, Aziz AA, Akib SM (2011) Impacts of land-use change on streamflows in the Damansara watershed, Malaysia. Arab J Sci Eng 36:713-720. https://doi.org/10.1007/ s13369-011-0075-3

Andersen J, Refsgaard JC, Jensen KH (2001) Distributed hydrological modelling of the Senegal River basin-Model construction and validation. J Hydrol 247:200-214. https://doi.org/10.1016/S0022 -1694(01)00384-5

Arnold JG, Neitsch SL, Kiniry JR, Williams JR, King KW (2005) Soil and water assessment tool (SWAT) theoretical documentation version 2005. Agriculture Research Service US. Texas. [terhubung Berkala]. http://www.Brc.Tamus.Edu/swat/document. html. Accessed 31 Oct 2008
Asmat A, Mansor S, Saadatkhah N, Adnan NA, Khuzaimah Z (2016) Land use change effects on extreme flood in the Kelantan basin using hydrological model. In: Tahir W, Abu Bakar PA, Wahid M, Mohd Nasir SM, Lee W (eds) ISFRAM 2015. Springer, Singapore, pp 221-236

Ayub KR, Hin LS, Aziz HA, Ampangan S, Tebal N, Perai S et al (2009) SWAT application for hydrologic and water quality modeling for suspended sediments: a case study of Sungai Langat catchment in Selangor. In: International conference on water resources (ICWR 2009), pp 26-27

Bárdossy A (2006) Calibration of hydrological model parameters for ungauged catchments. Hydrol Earth Syst Sci Dis 3:1105-1124. https://doi.org/10.5194/hessd-3-1105-2006

Basarudin Z, Adnan NA, Latif ARA, Tahir W, Syafiqah N (2014) Event-based rainfall-runoff modelling of the Kelantan River basin. IOP Conf Ser Earth Environ Sci 18:12084. https://doi. org/10.1088/1755-1315/18/1/012084

Bathurst JC, Ewen J, Parkin G, O'Connell PE, Cooper JD (2004) Validation of catchment models for predicting land-use and climate change impacts. 3. Blind validation for internal and outlet responses. J Hydrol 287:74-94. https://doi.org/10.1016/j.jhydr ol.2003.09.021

Beheshti Z, Firouzi M, Shamsuddin SM, Zibarzani M, Yusop Z (2016) A new rainfall forecasting model using the CAPSO algorithm and an artificial neural network. Neural Comput Appl 27:2551-2565. https://doi.org/10.1007/s0052 1-015-2024-7

Bellocchi G, Rivington M, Donatelli M, Matthews K, Bellocchi G, Rivington $M$ et al (2010) Validation of biophysical models: issues and methodologies. Sustain Agric 2:577-603. https:// doi.org/10.1051/agro/2009001

Boughton W (2006) Calibrations of a daily rainfall-runoff model with poor quality data. Environ Modell Softw 21:1114-1128. https://doi.org/10.1016/j.envsoft.2005.05.011

Box GEP, Jenkins GM (1970) Time series analysis: forecasting and control, 1976. ISBN: 0-8162-1104-3

Chang TK, Talei A, Alaghmand S, Ooi MPL (2017) Choice of rainfall inputs for event-based rainfall-runoff modeling in a catchment with multiple rainfall stations using data-driven techniques. J Hydrol 545:100-108. https://doi.org/10.1016/j. jhydrol.2016.12.024

Chong FS, Tan DNK (1986) Hydrogeological activities in Peninsular Malaysia and Sarawak. In: Geosea V proceedings, vol II, Geological Society Malaysia. Bulletin vol 20, pp 827-842

Chow VT, Maidment DR, Mays LW (1988) Applied hydrology, pp $12-34$

Devi GK, Ganasri BP, Dwarakish GS (2015) A Review on hydrological models. In: International conference on water resources, coastal and ocean engineering (ICWRCOE), pp 1001-1007. https://doi.org/10.1016/j.aqpro.2015.02.126

Dhanoa MS, Lister SJ, France J, Barnes RJ (1999) Use of mean square prediction error analysis and reproducibility measures to study near infrared calibration equation performance. J Near Infrared Spec 7:133-144

DID (Drainage and Irrigation Department) (1974) Hydrological regions of peninsular Malaysia

Dlamini NS, Rowshon MK, Fikhri A, Lai SH, Mohd MSF (2017) Modelling the streamflow of a river basin using enhanced hydro-meteorological data in Malaysia. Acta Hort 1152:291298. https://doi.org/10.17660/ActaHortic.2017.1152.39

Dooge J (1959) A general theory of the unit hydrograph. J Geoph Res 64:241-256

Engel BA, Flanagan DC (2006) Modeling and risk analysis of nonpoint-source pollution caused by atrazine using SWAT. Trans ASABE 49:667-678 
Fleming G (1972) Computer simulation techniques in hydrology. In: George $\mathrm{F}$ (ed) Computer simulation techniques in hydrology. Elsevier, Netherlands, pp 48-87

Fox DG (1981) Judging air quality model performance. Bull Am Meteorol Soc 62:599-609

Ghorbani K, Wayayok A, Abdullah AF (2016) Simulation of flood risk area in Kelantan watershed, Malaysia using numerical model. Jurnal Teknol 78:51-57

Goh YC, Zainol Z, Mat Amin MZ (2016) Assessment of future water availability under the changing climate: case study of Klang River Basin, Malaysia. Intern J River Basin Manag 5124:1-9. https://doi.org/10.1080/15715124.2015.1068178

Green IRA, Stephenson D (1986) Criteria for comparison of single event models. Hydrol Sci J 31:395-411

Gupta HV, Sorooshian S, Yapo PO (1999) Status of automatic calibration for hydrologic models: comparison with multilevel expert calibration. J Hydrol Eng 4:135-143

Hafiz I, Sidek LM, Basri H, Fukami K, Hanapi MN, Livia L, Jaafar AS (2014) Integrated flood analysis system (IFAS) for Kelantan River basin. In: IEEE 2nd international symposium on telecommunication technologies (ISTT), pp 159-162

Halwatura D, Najim MMM (2013) Environmental modelling \& software application of the HEC-HMS model for runoff simulation in a tropical catchment. Environ Modell Softw 46:155-162. https://doi.org/10.1016/j.envsoft.2013.03.006

Hasan ZA, Hamidon N, Suffian M (2009) Integrated river basin management (IRBM): hydrologic modelling using HEC-HMS for Sungai Kurau basin, Perak. In: International conference on water resources (ICWR 2009), pp 1147-1152. https://doi. org/10.1128/JVI.03540-12

Hassan Z, Shamsudin S, Harun S, Malek MA, Hamidon N (2015) Suitability of ANN applied as a hydrological model coupled with statistical downscaling model: a case study in the northern area of Peninsular Malaysia. Environ Earth Sci 74:463-477. https://doi.org/10.1007/s12665-015-4054-y

Haykin S (1999) Neural networks. Prentice Hall, New Jersey

Heng CL (2004) Groundwater utilisation and management in Malaysia. 41 St CCOP Annual Session 15-18 November 2004 Tsukuba, Japan, 83

Jaafar K, Ismail N, Tajjudin M, Adnan R, Hezri M, Rahiman F (2016) Hidden neuron variation in multi-layer perceptron for flood water level prediction at Kusial station faculty of electrical engineering. In: 2016 IEEE 12th international colloquium on signal processing \& its applications (CSPA2016), 4-6 March 2016, Melaka, Malaysia, pp 4-6. https://doi. org/10.1109/CSPA.2016.7515858

Jajarmizadeh M, Harun S, Salarpour M (2012) A Review on theoretical consideration and types of models in hydrology. J Eng Sci Tech 5:249-261

Jakeman AJ, Letcher RA, Norton JP (2006) Ten iterative steps in development and evaluation of environmental models. Environ Modell Softw 21:602-614. https://doi.org/10.1016/j.envsoft.2006.01.004

Johansson EM, Dowla FU, Goodman DM (1991) Backpropagation learning for multilayer feed-forward neural networks using the conjugate gradient method. Int J Neural Syst 2:291-301

Juahir H, Sultan U, Abidin Z, Azid A, Sultan U, Abidin Z et al (2015) Flood risk pattern recognition by using environmetric technique: a case study in Langat River basin. Jurnal Teknol. https://doi. org/10.11113/jt.v77.4142

Jun CL, Mohamed ZS, Peik AL, Razali SF, Sharil S (2016) Flood forecasting model using empirical method for a small catchment area. J Eng Sci Technol 11:666-672

Kabiri R, Chan A, Bai R (2013) Comparison of SCS and Green-Ampt methods in surface runoff-flooding simulation for Klang watershed in Malaysia. Open J Modern Hydrol 3:102-114. https://doi. org/10.4236/ojmh.2013.33014
Khalid K, Ali MF, Rahman NFA (2015) The development and application of Malaysian soil taxonomy in SWAT watershed model. In: Abu Bakar S, Tahir W, Wahid M, Mohd Nasir S, Hassan R (eds) ISFRAM 2014. Springer, Singapore, pp 77-88. https:// doi.org/10.1007/978-981-287-365-1

Khalid K, Ali MF, Faiza N, Rahman A, Mispan MR, Haron SH et al (2016a) Application of the SWAT hydrologic model in Malaysia: recent research. In: The challenges of agro-environmental research in Monsoon Asia, pp 237-246

Khalid K, Ali MF, Rahman NFA, Othman Z, Bachok MF (2016b) Calibration assessment of the distributed hydrologic model using SWAT-CUP. In: Regional conference on science, technology and social sciences (RCSTSS 2016). Springer, Singapore, pp. 241-250

Khalid K, Ali MF, Rahman NFA, Mispan MR (2016c) Application on one-at-a-time sensitivity analysis of semi-distributed hydrological model in tropical watershed. IACSIT Int J Eng Technol 8:132-136. https://doi.org/10.7763/IJET.2016.V8.872

Kia MB, Pirasteh S, Pradhan B, Mahmud AR, Sulaiman WNA, Moradi A (2012) An artificial neural network model for flood simulation using GIS: Johor River Basin, Malaysia. Environ Earth Sci 67:251-264. https://doi.org/10.1007/s1266 5-011-1504-Z

Krause P, Boyle DP, Bäse F (2005) Comparison of different efficiency criteria for hydrological model assessment. Adv Geosci 5:89-97

Kuok KK, Chiu PC, Chung CM, Chuang TH (2010) Relationship between storage coefficient and catchment area using HEC-HMS for Southern Region of Sarawak. IUP J Soil Water Sci 3:20-33

Kura NU, Ramli MF, Sulaiman WNA, Ibrahim S, Aris AZ (2015) An overview of groundwater chemistry studies in Malaysia. Adv Environ Chem Pollut. https://doi.org/10.1007/s1135 6-015-5957-6

Kwin CT, Talei A, Alaghmand S, Chua LHC (2016) Rainfall-runoff modeling using dynamic evolving neural fuzzy inference system with online learning. Proc Eng 154:1103-1109. https://doi. org/10.1016/j.proeng.2016.07.518

Legates DR, McCabe GJ (1999) Evaluating the use of "goodness-offit" measures in hydrologic and hydroclimatic model validation. Water Resour Res 35:233-241

Lippmann R (1987) An introduction to computing with neural nets. IEEE Assp Mag 4:4-22

Lu J, Sun G, Amatya DM, Harder SV, McNulty SG (2006) Understanding the hydrologic response of a coastal plain watershed to forest management and climate change in South Carolina, USA. In: Hydrology and management of forested wetlands, proceedings of the international conference, April 8-12, 2006, New Bern, North Carolina (pp 28). American Society of Agricultural and Biological Engineers

Mah DYS, Putuhena FJ, Said S (2007) Use of infoworks river simulation (RS) In Sungai Sarawak Kanan modeling. J Inst Eng Malays 68:1-9

Mah DYS, Putuhena FJ, Lai SH (2011) Modelling the flood vulnerability of deltaic Kuching City, Malaysia. Nat Hazards 58:865-875. https://doi.org/10.1007/s11069-011-9731-x

Mah DYS, Hii CP, Kho A (2017) Modelling approaches for minimally gauged Sg Similajau, Bintulu. J App Sci Proc Eng 4:2 e-ISSN: 2289-7771

Malek MA, Heyrani M, Juneng L (2015) Stream flow projection for Muar river in Malaysia using precis-HEC-HMS model. ASM Sci J 1:8-19

Manaf LA, Samah MAA, Zukki NIM (2009) Municipal solid waste management in Malaysia: Practices and challenges. Waste Manag 29:2902-2906

McCuen RH (1998) Hydrologic analysis and design. Prentice Hall, New Jersey 
McCuen RH, Knight Z, Cutter AG (2006) Evaluation of the NashSutcliffe efficiency Index. J Hydrol Eng 11:597-602. https:// doi.org/10.1061/(ASCE)1084-0699(2006)11:6(597)

Mohd MSF, Mispan MR, Juneng L, Tangang FT, Rahman NFA, Khalid K, Rashid MZA, Haron SH (2015) Assessment of impacts of climate change on road transport. ARPN J Eng Appl Sci 10:6634-6642

Mohtar ISA, Tahir W, Bakar SHA, Zuhari AZM (2015) Use of numerical weather prediction model and visible weather satellite images for flood forecasting at Kelantan river basin. In: Bakar S, Tahir W, Wahid M, Nasir S, Hassan R (eds) ISFRAM 2014. Springer, Singapore, pp 283-294. https://doi. org/10.1007/978-981-287-365-1

Moriasi D, Wilson B (2012) Hydrologic and water quality models: use, calibration, and validation. Trans ASABE 55:1241-1247. https://doi.org/10.13031/2013.42265

Moriasi DN, Arnold JG, Liew MW et al (2007) Model evaluation guidelines for systematic quantification of accuracy in watershed simulations. Trans ASABE 50:885-900

Mustafa YM, Amin MSM, Lee TS, Shariff ARM (2012) Evaluation of land development impact on a tropical watershed hydrology using remote sensing and GIS. J Spat Hydrol 5:16-30

Mustafa Z, Awang A, Abdullah A (2018) Effects of tides on the hydrology and geometry of a freshwater channel J Fundamental Appl Sci. https://doi.org/10.4314/jfas.v10i1s.56 (ISSN 1112-9867)

Nash JE (1959) Systematic determination of unit hydrograph parameters. J Geoph Res 64:111. https://doi.org/10.1029/JZ064i001p 00111

Nash JE, Sutcliffe JV (1970) River flow forecasting through conceptual models part I-a discussion of principles. J Hydrol 10:282-290. https://doi.org/10.1016/0022-1694(70)90255-6

Nasir KAM, Hashim NB, Kazemi Z, Aslani H (2015) Application of the HEC-HMS model for storm events case study: Pendas River, Malaysia. In: International congress on civil engineering, architecture and urban development

Nejadhashemi AP, Wardynski BJ, Munoz JD (2011) Evaluating the impacts of land use changes on hydrologic responses in the agricultural regions of Michigan and Wisconsin. Hydrol Earth Syst Sci Disc 8:3421-3468. https://doi.org/10.5194/hessd -8-3421-2011

Nor NI, Harun S, Kassim AH (2007) Radial basis function modeling of hourly streamflow hydrograph. J Hydrol Eng 12:113-123. https ://doi.org/10.1061/(ASCE)1084-0699(2007)12:1(113)

Norzilah A, Ahmad MF, Jusoh A, Tofany N, Yaacob R, Muslim AM (2016) Hydrodynamics modelling at Setiu wetland, Terengganu. J Environ Sci Tech 9:437-445. https://doi.org/10.3923/ jest.2016.437.445

Omang SA, Tahir SH (1994) Cretaceous and Neogene lavas of Sabah origin and tectonic significance Kuala Terengganu, Malaysia. Geol Soc Malay Bull 21-30

Penman HL (1961) Weather, plant and soil factors in hydrology. Weather 16:207-219

Perera EDP, Lahat L (2014) Fuzzy logic based flood forecasting model for the Kelantan River basin, Malaysia. J Hydro-Environ Res. https://doi.org/10.1016/j.jher.2014.12.001

Pradhan B (2009) Flood susceptible mapping and risk area delineation using logistic regression, GIS and remote sensing. J Spat Hydrol 9:2

Pradhan B, Youssef AM (2011) A 100-year maximum flood susceptibility mapping using integrated hydrological and hydrodynamic models: Kelantan River Corridor, Malaysia. J Flood Risk Manag 4:189-202. https://doi.org/10.1111/j.1753-318X.2011.01103.x

Pradhan B, Shafiee M, Pirasteh S (2009) Maximum flood prone area map RADARSAT images and GIS: Kelantan River basin. Intern J Geomat 5:11-23
Press WH, Teukolsky SA, Vetterling WT, Flannery BP (1992) Numerical recipes in Fortran 77: the art of scientific computing. Cambridge university press, Cambridge

Rabuñal JR, Puertas J, Suárez J, River D (2007) Determination of the unit hydrograph of a typical urban basin using genetic programming and artificial neural networks. Hydrol Proc 21:476485. https://doi.org/10.1002/hyp

Rahim BEE, Yusoff I, Jafri AM, Othman Z, Abdul Ghani A (2012) Application of MIKE SHE modelling system to set up a detailed water balance computation. Water Environ J 26:490503. https://doi.org/10.1111/j.1747-6593.2012.00309.x

Ramly S, Tahir W (2016) Application of HEC-GeoHMS and HEC-HMS as rainfall-runoff model for flood simulation. ISFRAM 2015. Springer, Singapore, pp 181-192. https://doi. org/10.1007/978-981-10-0500-8_15

Ray K (1975) Hydrology for engineers. McGraw Hill, Kogakusha

Razi MAM, Ariffin J, Tahir W, Arish NAM (2010) Flood estimation studies using hydrologic modeling system (HEC-HMS) for Johor River, Malaysia. J Appl Sci 10:930-939

Refsgaard JC (1996) The role of distributed hydrological modelling in water resources management. In: Abbott MB, Refsgaard JC (eds) Distributed hydrological modelling. Springer, Germany. https://doi.org/10.1007/978-94-009-0257-2

Refsgaard JC, Storm B (1995) MIKE SHE. Comput Models Watershed Hydrol 1:809-846

Romali NS, Yusop Z, Ismail AZ (2018) Hydrological modelling using HEC-HMS for flood risk assessment of Segamat Town, Malaysia. IOP Conf Ser Mater Sci Eng 318(1):012029

Romaly NS, Yusop Z, Ismail AZ (2018) Application of HEC-RAS and Arc GIS for floodplain mapping in Segamat town, Malaysia. Intern J GEOMATE 2186-2990 https://doi.org/10.21660 /2018.43.3656

Ros FC, Sidek LM, Ibrahim NNN, Razad AA (2008) Probable maximum flood (PMF) for the Kenyir Catchment, Malaysia. In: International conference on construction and building technology, pp 325-334

Saadatkhah N, Tehrani MH, Mansor S, Khuzaimah Z, Kassim A, Saadatkhah R (2016) Impact assessment of land cover changes on the runoff changes on the extreme flood events in the Kelan$\tan$ River basin. Arab J Geos 9:687. https://doi.org/10.1007/ s12517-016-2716-z

Saghafian B, Khosroshahi M (2005) Unit response approach for priority determination of flood source areas. J Hydrol Eng 10:270-277. https://doi.org/10.1061/ (ASCE)1084-0699(2005)10:4(270)

Saghafian B, Farazjoo H, Bozorgy B, Yazdandoost F (2008) Flood intensification due to changes in land use. Water Resour Manag 22:1051-1067. https://doi.org/10.1007/s11269-007-9210-z

Santhi C, Arnold JG, Williams JR, Hauck LM, Dugas WA (2001) Application of a watershed model to evaluate management effects on point and nonpoint source pollution. Trans ASABE 44:1559-1570

Shamsudin S, Dan'azumi S, Ab Rahman A (2011) Uncertainty analysis of HEC-HMS model parameters using Monte Carlo simulation. Intern J Modell Simul 31:279-286

Shaw EM, Beven KJ, Chappell NA, Lamb R (2010) Hydrology in practice. CRC Press, New York

Sherman LK (1932) Streamflow from rainfall by the unit-graph method. Eng News Record 108:501-505

Singh VP (1995) Computer models of watershed hydrology, vol 1130. Water Resources Publications, Highlands Ranch, CO

Singh VP, Woolhiser DA (2002) Mathematical modeling of watershed hydrology. J Hydrol Eng 7:270-292

Sulaiman WNA, Heshmatpoor A, Rosli MH (2010) Identification of flood source areas in Pahang River basin. Penins Malays Environ Asia 3:73-78 
Sulaiman M, El-Shafie A, Karim O, Basri H (2011) Improved water level forecasting performance by using optimal steepness coefficients in an artificial neural network. Water Resour Manag 25:2525-2541. https://doi.org/10.1007/s11269-011-9824-z

Sulaiman AHA, Katimon A, Darus IZM, Shahid S (2016) TOPMODEL for streamflow simulation of a tropical catchment using different resolutions of ASTER DEM: optimization through response surface methodology. Water Resour Manag 30:3159-3173. https ://doi.org/10.1007/s11269-016-1338-2

Suparta W, Putro WS, Singh MSJ, Asillam MF (2015) The estimation of rainfall and precipitation variation during 2011 convective system using an artificial neural network over Tawau, Sabah. In: International conference on space science and communication, IconSpace, pp 479-484. https://doi.org/10.1109/IconS pace. 2015.7283806

Tahir W, Hamid HAC (2013) Flood forecasting using tank model and weather surveillance radar (WSR) input for Sg Gombak. Intern J Civ Environ Eng 13:42-46. http://www.ijens.org/ Vol_13_I_02/133202-5757-IJCEE-IJENS.pdf. Accessed 28 Nov 2015

Tan ML, Ibrahim AL, Yusop Z, Duan Z, Ling L (2014) Impacts of land-use and climate variability on hydrological components in the Johor River basin, Malaysia. Hydrol Sci J 60:873-889. https ://doi.org/10.1080/02626667.2014.967246 (141217125340005)

Tayebiyan A, Mohammad TA, Ghazali AH, Mashohor S (2016) Artificial neural network for modelling rainfall-runoff. Pertanika $\mathbf{J}$ Sci Tech 24:319-330. https://www.scopus.com/inward/record. uri?eid=2-s2.0-84974678275\&partnerID $=40 \& \mathrm{md5}=\mathrm{aa} 6 \mathrm{e} 6166$ c170cda304b4434d38cf306c

Tehrany MS, Pradhan B, Jebur MN (2013) Spatial prediction of flood susceptible areas using rule based decision tree (DT) and a novel ensemble bivariate and multivariate statistical models in GIS. J Hydrol 504:69-79. https://doi.org/10.1016/j.jhydrol.2013.09.034

Tehrany MS, Pradhan B, Jebur MN (2014) Flood susceptibility mapping using a novel ensemble weights-of-evidence and support vector machine models in GIS. J Hydrol 512:332-343. https:// doi.org/10.1016/j.jhydrol.2014.03.008

Tehrany MS, Pradhan B, Jebur MN (2015) Flood susceptibility mapping using a novel ensemble weights-of-evidence and support vector machine models in GIS. Stoch Environ Res Risk Assess 512:332-343. https://doi.org/10.1016/j.jhydrol.2014.03.008
Todini E, Wallis JR (1977) Using CLS for daily or longer period rainfall-runoff modelling. Math Models Surf Water Hydrol 100:149-168

UNPF (2015) United Nations Population Fund state of the world population 2015: unlasshing the potential of urban growth. New York City, United States

USACE-HEC (2000) Hydrologic modeling system HEC-HMS: technical reference manual. California, USA

USACE-HEC (2010) Hydrologic modeling system, HEC-HMS user's manual. United States Army Corp of Engineers, Hydrologic Engineering Centre

Verma AK, Jha MK, Mahana RK (2010) Evaluation of HEC-HMS and WEPP for simulating watershed runoff using remote sensing and geographical information system. Paddy Water Environ 8:131-144. https://doi.org/10.1007/s10333-009-0192-8

Willmott CJ (1982) Some comments on the evaluation of model performance. Bull Am Meteorol Soc 63:1309-1313

Wong CL, Venneker R, Uhlenbrook S (2010) Analysis and modelling of runoff from two distinct river basins in Peninsular Malaysia. In: HydroPredict conference, $\mathrm{p} 11$

Wong CL, Venneker R, Jamil ABM, Uhlenbrook S (2011) Development of a gridded daily hydrometeorological data set for Peninsular Malaysia. Hydrol Proc 25:1009-1020. https://doi. org/10.1002/hyp.7654

Woolhiser DA (1973) Hydrologic and watershed modeling-state of the art. Trans ASABE 16:553-559

Wurbs RA (1998) Dissemination of generalized water resources models in the United States. Water Intern 23:190-198

Yaseen ZM, El-Shafie A, Afan HA, Hameed M, Mohtar WHMW, Hussain A (2016) RBFNN versus FFNN for daily river flow forecasting at Johor River, Malaysia. Neural Comput App 27:1533-1542. https://doi.org/10.1007/s00521-015-1952-6

Yeganeh N, Sabri S (2014) Flood vulnerability assessment in Iskandar Malaysia using multi-criteria evaluation and fuzzy logic. J App Sci Eng Technol 8:1794-1806

Yusop Z, Chan CH, Katimon A (2007) Runoff characteristics and application of HEC-HMS for modelling stormflow hydrograph in an oil palm catchment. Water Sci Tech 56:41. https://doi. org/10.2166/wst.2007.690 